Izvorni rad

UDK: 004:65.01:316.663:316.64/.65:658

Datum primitka članka u uredništvo: 25. 10. 2021.

Datum slanja članka na recenziju: 26. 10. 2021.

Datum prihvaćanja članka za objavu: 6. 12. 2021.

Doc. dr. sc. Igor Klopotan *

\title{
POVEZANOST KVALITETE ONLINE KOMUNICIRANJA DRUŠTVENO ODGOVORNOG POSLOVANJA I REPUTACIJE PODUZEĆA
}

\section{THE RELATIONSHIP BETWEEN THE QUALITY OF ONLINE COMMUNICATION OF SOCIALLY RESPONSIBLE BUSINESS AND THE REPUTATION OF THE COMPANY}

SAŽETAK: Između društvene odgovornosti poduzeća i reputacije postoji višedimenzionalna povezanost kroz imidž, konkurentnost i povjerenja između poduzeća i dionika. Znanstvena istraživanja pokušala su doprinijeti i razviti modele mjerenja i upravljanja reputacijom poduzeća, ali još je uvijek vrlo malo istraživanja koja povezuju društveno odgovorno poslovanje s reputacijom poduzeća. Razina društvene odgovornosti, prema istraživanjima, utječe na indeks reputacije kao jedan od bitnih parametara. Glavno istraživačko pitanje ovog rada jest utječe li komuniciranje društveno odgovornog poslovanja putem mrežnih stranica i društvenih mreža na reputaciju poduzeća u Republici Hrvatskoj. Provedena su dva primarna istraživanja: (i) istraživanje reputacije poduzeća na uzorku stanovništva i (ii) primarno istraživanje mrežnih stranica poduzeća i društvenih mreža. Metodom kvantilne regresije ispitane su hipoteze rada, koje su i potvrđene.

KLJUČNE RIJEČI: društveno odgovorno poslovanje, reputacija, kvantilna regresija, mrežne stranice, društvene mreže

ABSTRACT: There is a multidimensional connection between corporate social responsibility and reputation through image, competitiveness and trust between the company and stakeholders. Scientific research has tried to contribute to and develop models for measuring and managing a company's reputation, but there is still very little research linking corporate social responsibility to a company's reputation. The level of social responsibility, according to research, affects the reputation index as one of the essential parameters. The main research question of this paper is whether the communication of socially responsible business through websites and social networks has an impact on the reputation of companies in the Republic of Croatia. Two primary surveys were conducted: (i) Enterprise repu-

Doc. dr. sc. Igor Klopotan, Međimursko veleučilište u Čakovcu, igor.klopotan@mev.hr 
tation survey on a sample of the population and (ii) Primary survey of enterprise websites and social networks. The hypotheses of the work were tested and confirmed by the quantile regression method.

KEY WORDS: socially responsible business, reputation, quantile regression, websites, social networks

\section{UVOD}

Informacija je postala jedan od najvažnijih resursa organizacije u današnje vrijeme (Čavić 2010; Samson i dr. 2014). Vrijednost informacija vidi se u: (i) traženju poteza konkurencije, (ii) dobivanju informacija oko želja i potreba korisnika koje omogućuju razvijanje boljih usluga i proizvoda, (iii) poslovanju koje mora pratiti zakonsku regulativu, a vještina komunikacije važnija je nego ikada prije, kako u obveznim izvještajima tako i u međusobnoj suradnji (Jiang 2010). Primarna upotreba interneta jest u svrhu informiranja (Ozretić Došen i dr. 2003). Ciljevi poduzeća utječu na motive izrade mrežnih stranica, a najčešći su: izgradnja imidža, podrška prodaji, snižavanje troškova, davanje informacija javnosti i slično (Bosilj Vukšić i Pejić Bach 1998; 1999).

Reputacija poduzeća dio je neopipljive imovine, uz intelektualni kapital i organizacijsku imovinu, čija vrijednost u posljednje vrijeme raste, a u nekim slučajevima nadmašuje i vrijednost same kompanije. Značaj reputacije poduzeća dobiva na važnosti otkada je reputacija stavljena kao značajna komponenta konkurentnosti poduzeća (Azad i Hassanabadi 2013). Niti je se može kupiti niti se njome može trgovati, ne može se nadomjestiti, a može biti izgubljena u trenutku (Grgić 2008). Reputacija nije ni pod čijom izravnom kontrolom pa je teško manipulirati njome. Reputacija se sastoji od percepcija, a za poduzeće je ključna ona kako nas drugi vide i doživljavaju (Starešinić i dr. 2019). Svaka interesna skupina koja okružuje poduzeće ima svoja očekivanja, perspektive i interese. Svaka od tih interesnih skupina ima svoju temu na koju želi odgovore, informacije i komentare. Mediji traže senzaciju, korisnici pouzdanog partnera sa stabilnom kvalitetom, zaposlenici dobre uvjete rada i plaće, dok vlada i zajednica imaju djelomično i zajedničke teme i očekivanja. Vladu interesira zaposlenost, uplata poreza i doprinosa, utjecaj poslovanja na okoliš i drugo, dok zajednicu interesira društvena odgovornost poduzeća. Jedna od ključnih stvari kojom poduzeće izgrađuje reputaciju u zadnje vrijeme jest dobra komunikacija i dobar odnos s užom i širom zajednicom. Tu spada i dobra komunikacija društvene odgovornosti poduzeća.

Društvena odgovornost postala je iznimno važno pitanje generirano brojnim promjenama koje su prisutne u okolišu te ona postaje jedna od najvažnijih stavki u odnosima s javnošću (Kolić-Stanić i dr. 2019; Božić 2020), uz važnost suradnje s dionicima (Barić 2017; Barić 2019; Butković i dr. 2021). Izvještavanje o društvenoj odgovornosti nije obvezno u većini zemalja pa se poduzeća kao samo regulatorni okvir često koriste Smjernicama za izvještavanje o održivosti (Kundid i Rogošić 2012). Navedene smjernice temelje se na okviru GRI-ja (Global Reporting Initiative). Izvještavanje o održivosti, prema okviru GRI-ja, praksa je mjerenja, objavljivanja i polaganja računa unutarnjim i vanjskim dionicima u vezi s učinkom u cilju održivog razvoja. Izvještavanje o održivosti širok je termin istoznačan s terminima kojima se koristi za opisivanje izvještavanja o ekonomskim, okolišnim i društvenim utjecajima (GRI 2014). Izvješća o održivosti objavljuju ishode i rezultate ostvarene unutar izvještajnog raz- 
doblja u kontekstu obveza, strategije i pristupa upravljanja organizacijom. Okvir izvještavanja GRI-ja trebao bi služiti kao općeprihvaćeni okvir za izvještavanje o ekonomskom, okolišnom i društvenom učinku neke organizacije (Legendre i Coderre 2013). Okvir izvještavanja prihvaćen je od strane dionika s obzirom na opću primjenjivost za izvještavanje o učinku održivosti organizacije. Izvještavanje se sastoji od triju dijelova: (i) određivanja sadržaja, kvalitete i granice izvješća, (ii) standardnih podataka i (iii) uputa za izvještavanje (Rodolfo 2012).

Dosadašnja istraživanja o mrežnim stranicama fokusirana su na pojedine djelatnosti kao što su hotelijerstvo (Jaković i dr. 2005; Pejić Bach i dr. 2007), maloprodaja (Knežević i dr. 2007), proizvodnja šećera i slatkiša (Knežević i dr. 2011), kao i online prodaja sportskih proizvoda (Pejić Bach i dr. 2010). Prvo istraživanje o izvještavanju koje se odmiče od granica tradicionalnog financijskog izvještavanja u Hrvatskoj, provedeno je 2005. godine, te je utvrđeno da hrvatska poduzeća koja kotiraju na burzi nemaju praksu izvještavanja na internetu (Pervan 2006). Srodno istraživanje, provedeno 2008. godine utvrdilo je da praksu detaljnijeg izvještavanja na službenim mrežnim stranicama imaju uspješnija poduzeća (Rogošić i dr. 2008). Istraživanja provedena u inozemstvu opseg objavljenih informacija dovode u korelaciju s veličinom poduzeća, gdje veliki poduzetnici dobrovoljno objavljuju širi spektar informacija o poslovanju (Kundid i Rogošić 2012). Dosadašnja istraživanja nisu u dovoljnoj mjeri istražila povezanost reputacije poduzeća i komuniciranja društveno odgovornog poslovanja (DOP) putem mrežnih stranica i društvenih medija. Na temelju istraživanja koje su proveli Hartman et al. (2007) o utjecaju kvalitete komuniciranja DOP-a na reputaciju poduzeća, ali kojim nisu obuhvaćene mrežne stranice i društvene mreže, razvijene su hipoteze ovog rada. Pri tome se mjerenje reputacije poduzeća definira korištenjem instrumenta koje je razvio Grgić (2008), a koji obuhvaća tri dimenzije (proizvodi i usluge, vodstvo i radno okruženje), koje su definirane na sljedeći način: (i) H1: kvaliteta komuniciranja DOP-a putem mrežnih stranica i društvenih mreža poduzeća statistički značajno povećava reputaciju proizvoda i usluga poduzeća; (ii) H2: kvaliteta komuniciranja DOP-a putem mrežnih stranica i društvenih mreža poduzeća statistički značajno povećava reputaciju vodstva poduzeća; (iii) H3: kvaliteta komuniciranja DOP-a putem mrežnih stranica i društvenih mreža poduzeća statistički značajno povećava reputaciju radnog okruženja poduzeća. Kako bi se ispitale navedene hipoteze, provedeno je empirijsko istraživanje na uzorku hrvatskih poduzeća, pri čemu je korištena kvantilna regresija.

Rad je formiran na sljedeći način. Nakon uvodnog poglavlja, drugo poglavlje prikazuje metodologiju istraživanja, pri čemu se fokusira na podatke, istraživački instrument i metodu analize. Treće poglavlje prikazuje rezultate istraživanja, dok četvrto poglavlje diskutira rezultate istraživanja uz zaključna razmatranja.

\section{Metodologija}

\section{Opis uzorka}

Kako bi se ispitale hipoteze ovoga rada provedena su dva istraživanja: (i) istraživanje reputacije poduzeća na uzorku stanovništva i (ii) primarno istraživanje mrežnih stranica poduzeća i društvenih mreža. Istraživanje reputacije poduzeća na uzorku stanovništva provedeno je kako bi se mjerila reputacija poduzeća s obzirom na proizvode i usluge, vodstvo i radno okruženje. Primarno empirijsko anketno istraživanje provedeno je na populaciji hrvatskog stanovništva, gdje su izvještajne jedinice građani u dobi od 18 do 65 godina. 
Istraživanje je provedeno metodom CAWI (engl. Computer-assisted web interviewing) uz korištenje internetskog upitnika, slanjem poveznice putem baze e-adresa, koja je formirana za potrebe ovog istraživanja. Baza se sastoji od 5000 e-adresa građana Republike Hrvatske u dobi od 18 do 65 godina. Odabirom svake pete e-adrese iz baze dobiven je uzorak od 1000 ispitanika kojima je poslana poveznica na anketu, te je prikupljeno 400 odgovora ispitanika. Instrument istraživanja sastoji se od skupa tvrdnji na koje ispitanici odgovaraju izražavajući svoje slaganje ili neslaganje, pri čemu se koristilo Likertovom ljestvicom sa sedam stupnjeva, određenom skalom od ,u potpunosti se slažem“ do „uopće se ne slažem“. Također se koristilo istraživačkim instrumentom koji je razvio Grgić (2012), a kojim se formira indeks reputacije poduzeća. Primarno istraživanje mrežnih stranica poduzeća i društvenih mreža provodi se kako bi se istražila kvaliteta komuniciranja DOP-a. Primarnim empirijskim istraživanjem prikupljeni su podaci o kvaliteti komuniciranja DOP-a putem mrežnih stranica poduzeća sukladno Smjernicama za izvještavanje o održivosti (Kundid i Rogošić 2012), a koje se temelje na okviru GRI-ja (uzorak od 100 poduzeća). Navedene smjernice korištene su prilikom definiranja kvalitete komuniciranja DOP-a kroz praksu mjerenja, objavljivanja i polaganja računa unutarnjim i vanjskim dionicima u vezi s učinkom u cilju održivog razvoja.

\section{Istraživački instrument}

Istraživački instrument kvalitete komuniciranja DOP-a putem mrežnih stranica prikazan je u Tablici 1., a sastoji se od šest dimenzija kvalitete komuniciranja: ravnoteže, usporedivosti, točnosti, pravodobnosti, jasnoće i pouzdanosti. Dimenzija ravnoteže mjeri se kroz skupinu varijabli $\mathrm{R}$, dimenzija usporedivost mjeri se kroz skupinu varijabli $\mathrm{U}$, dimenzija točnosti mjeri se kroz skupinu varijabli T, dimenzija pravodobnosti mjeri se kroz skupinu varijabli PRAV, dimenzija jasnoće mjeri se kroz skupinu varijabli J i dimenzija pouzdanosti mjeri se kroz skupinu varijabli POU. Također, formirane su skupne varijable R_avg, U_avg, T_avg, PRAV_avg, J_avg i POU_avg, koje su izračunate kao prosječne vrijednosti pojedinih varijabli, uz prethodnu provjeru korištenjem Cronbachovim alfa koeficijentom. Ovaj istraživački instrument formiran je na temelju Smjernica za izvještavanje o održivosti (Kundid i Rogošić 2012), a koje se temelje na okviru GRI-ja.

Tablica 1. Istraživački instrument kvalitete komuniciranja DOP-a putem mrežnih stranica

\begin{tabular}{|c|c|}
\hline $\begin{array}{c}\text { Šifra } \\
\text { varijable }\end{array}$ & Opis varijable \\
\hline \multicolumn{2}{|r|}{ Dimenzija komuniciranja DOP-a: Ravnoteža } \\
\hline $\mathrm{R} 1$ & R1. Mrežne stranice iznose povoljne i nepovoljne rezultate i teme \\
\hline $\mathrm{R} 2$ & $\begin{array}{l}\text { R2. Informacije na mrežnim stranicama iznesene su u formatu koji } \\
\text { korisnicima omogućuje uvid u pozitivne i negativne trendove glede učinka iz } \\
\text { godine u godinu }\end{array}$ \\
\hline $\mathrm{R} 3$ & $\begin{array}{l}\text { R3. Naglasak na različitim temama na mrežnim stranicama razmjeran je } \\
\text { njihovoj relativnoj materijalnosti }\end{array}$ \\
\hline \multicolumn{2}{|r|}{ Dimenzija komuniciranja DOP-a: Usporedivost } \\
\hline U1 & $\begin{array}{l}\text { U1. Podaci na mrežnim stranicama o društvenoj odgovornosti mogu se } \\
\text { uspoređivati iz godine u godinu }\end{array}$ \\
\hline
\end{tabular}




\begin{tabular}{|c|c|}
\hline $\begin{array}{c}\text { Šifra } \\
\text { varijable }\end{array}$ & Opis varijable \\
\hline $\mathrm{U} 2$ & $\begin{array}{l}\text { U2. Učinak organizacije može se uspoređivati s oglednim vrijednostima } \\
\text { (engl. benchmarks) }\end{array}$ \\
\hline U3 & $\begin{array}{l}\text { U3. Svaka značajna promjena između izvještajnih razdoblja koja se odnosi } \\
\text { na granicu, opseg, duljinu izvještajnog razdoblja ili iznesenu informaciju na } \\
\text { mrežnoj stranici može se jasno prepoznati i objasniti }\end{array}$ \\
\hline $\mathrm{U} 4$ & $\begin{array}{l}\text { U4. Ondje gdje su dostupni, mrežna stranica koristi se općeprihvaćenim } \\
\text { protokolima za sastavljanje, mjerenje i prikaz podataka, uključujući GRI-jeve } \\
\text { Protokole uz pokazatelje sadržane u Smjernicama }\end{array}$ \\
\hline U5 & U5. Mrežna stranica prikazuje Sektorske dodatke GRI-ja \\
\hline \multicolumn{2}{|r|}{ Dimenzija komuniciranja DOP-a: Točnost } \\
\hline $\mathrm{T} 1$ & T1. Mrežna stranica navodi podatke koji su izmjereni \\
\hline $\mathrm{T} 2$ & $\begin{array}{l}\text { T2. Tehnike mjerenja podataka i osnove za izračune primjereno su opisane i } \\
\text { mogu se replicirati sa sličnim rezultatima }\end{array}$ \\
\hline $\mathrm{T} 3$ & $\begin{array}{l}\text { T3. Odstupanje brojčanih podataka nedostatno je da bi u znatnoj mjeri } \\
\text { utjecalo na sposobnost dionika za donošenje primjerenih i zasnovanih } \\
\text { zaključaka o učinku }\end{array}$ \\
\hline $\mathrm{T} 4$ & $\begin{array}{l}\text { T4. Mrežna stranica upućuje na podatke zasnovane na procjenama te navodi } \\
\text { temeljne pretpostavke i tehnike korištene za dobivanje procjena ili, pak, } \\
\text { navodi izvor informacije }\end{array}$ \\
\hline T5 & $\begin{array}{l}\text { T5. Brojčani navodi u izvješću valjani su na osnovi drugih iznesenih } \\
\text { informacija i drugih dostupnih dokaza }\end{array}$ \\
\hline \multicolumn{2}{|r|}{ Dimenzija komuniciranja DOP-a: Pravodobnost } \\
\hline PRAV1 & $\begin{array}{l}\text { PRAV1. Informacija objavljena na mrežnoj stranici još je nedavna s obzirom } \\
\text { na izvještajno razdoblje }\end{array}$ \\
\hline PRAV2 & $\begin{array}{l}\text { PRAV2. Prikupljanje i objavljivanje ključnih informacija o učinku usklađeno } \\
\text { je s rasporedom izvještavanja o održivosti }\end{array}$ \\
\hline PRAV3 & $\begin{array}{l}\text { PRAV3. Informacija iznesena na mrežnoj stranici (uključujući i onu } \\
\text { predstavljenu na mrežnim stranicama) jasno navodi razdoblje na koje se } \\
\text { odnosi, kada će biti ažurirana i kada je izvršena zadnja nadopuna }\end{array}$ \\
\hline \multicolumn{2}{|r|}{ Dimenzija komuniciranja DOP-a: Jasnoća } \\
\hline $\mathrm{J} 1$ & $\begin{array}{l}\text { J1. Mrežna stranica sadržava razinu informacije koju traže dionici, ali } \\
\text { izbjegava pretjerane i nepotrebne detalje }\end{array}$ \\
\hline $\mathrm{J} 2$ & $\begin{array}{l}\text { J2. Dionici mogu naći željenu informaciju bez truda koji prelazi razumnu } \\
\text { mjeru, pomoću pregleda sadržaja, pretraživanja interneta, internetskih } \\
\text { poveznica ili drugih pomagala }\end{array}$ \\
\hline $\mathrm{J} 3$ & $\begin{array}{l}\text { J3. Mrežna stranica izbjegava upotrebu tehničkih termina, skraćenica, žargona } \\
\text { ili drugog sadržaja s kojima dionici vjerojatno nisu upoznati, te uključuje i } \\
\text { obrazloženja (gdje je to potrebno) u relevantnim poglavljima ili u pojmovniku }\end{array}$ \\
\hline J4 & $\begin{array}{l}\text { J4. Podaci i informacije u izvješću dostupni su dionicima, uključujući i one } \\
\text { dionike s posebnim potrebama u pogledu dostupnosti (na primjer, s obzirom } \\
\text { na različite mogućnosti, jezike ili tehnologiju) }\end{array}$ \\
\hline
\end{tabular}




\begin{tabular}{|l|l|}
\hline $\begin{array}{c}\text { Šifra } \\
\text { varijable }\end{array}$ & \multicolumn{1}{c|}{ Opis varijable } \\
\hline \multicolumn{2}{|c|}{ Dimenzija komuniciranja DOP-a: Pouzdanost } \\
\hline POU1 & POU1. Utvrđen je opseg i stupanj vanjske verifikacije \\
\hline POU2 & $\begin{array}{l}\text { POU2. Organizacija može navesti izvor informacija korištenih na mrežnoj } \\
\text { stranici }\end{array}$ \\
\hline POU3 & $\begin{array}{l}\text { POU3. Organizacija može ukazati na pouzdane dokaze koji potkrepljuju } \\
\text { pretpostavke ili složene izračune }\end{array}$ \\
\hline POU4 & $\begin{array}{l}\text { POU4. Na raspolaganju je prikaz izvornih vlasnika podataka ili informacija, } \\
\text { koji mogu posvjedočiti njihovu točnost unutar prihvatljivih odstupanja }\end{array}$ \\
\hline
\end{tabular}

Izvor: autorski rad prema GRI-ju; Kundid i Rogošić, 2012.

Napomena: Likertova skala $1-5$

Istraživački instrument reputacije poduzeća prikazan je u Tablici 2., a sastoji se od tri dimenzije reputacije: reputacije vezane uz proizvode i usluge, reputacije vezane uz viziju poduzeća i reputacije vezane uz radne odnose. Dimenzija reputacije poduzeća vezane uz proizvode i usluge mjeri se kroz skupinu varijabli $\mathrm{P}$, dimenzija reputacije poduzeća vezane uz viziju poduzeća mjeri se kroz skupinu varijabli VIZ i dimenzija reputacije poduzeća vezane uz radne odnose mjeri se kroz skupinu varijabli RO. Također, formirane su skupne varijable P_avg, VIZ_avg i RO_avg, koje su izračunate kao prosječne vrijednosti pojedinih varijabli, uz prethodnu provjeru korištenjem Cronbachovim alfa koeficijentom. Ovaj istraživački instrument formiran je na temelju Fombrunova modela, koji se naziva kvocijent reputacije (Fombrun i dr. 2000: 253), a korišten je u mnogim istraživanjima reputacije poduzeća i banaka (Grgić 2012: 29).

Tablica 2. Istraživački instrument reputacije poduzeća

\begin{tabular}{|l|l|}
\hline $\begin{array}{c}\text { Šifra } \\
\text { varijable }\end{array}$ & \\
\hline & Reputacija poduzeća: proizvodi i usluge \\
\hline P1 & Garancija proizvoda i usluga \\
\hline P2 & Razvoj inovativnih usluga \\
\hline P3 & Kvaliteta proizvoda i usluga \\
\hline P4 & Razina usluga i proizvoda za danu cijenu (vrijednost za novac) \\
\hline & Reputacija poduzeća: vizija \\
\hline VIZ1 & Menadžment poduzeća \\
\hline VIZ2 & Vizija budućnosti \\
\hline VIZ3 & Kvaliteta vodstva \\
\hline & Reputacija poduzeća: radni odnosi \\
\hline RO1 & Kvaliteta poduzeća kao poslodavca \\
\hline RO2 & Kvaliteta zaposlenika \\
\hline
\end{tabular}

Izvor: autorski rad prema Fombrun i dr., 2000., str. 253; Grgić, 2012., str. 29

Napomena: Likertova skala $1-7$ 


\section{Ispitivanje hipoteza}

Hipoteza H1 ispitana je na sljedeći način. Kao zavisna varijabla korištena je skupna varijabla dimenzije reputacije vezane uz proizvode i usluge $P_{-}$avg. Kao nezavisne varijable korištene su varijable kvalitete komuniciranja DOP-a putem mrežnih stranica i društvenih mreža. U modelima su također korištene i kontrolne varijable kojima se iskazuju karakteristike tržišta i poduzeća iz uzorka. Hipoteza je testirana na cijelom istraživačkom uzorku metodom linearne regresije. Budući da je model linearne regresije pokazao kako kod poduzeća koja imaju vrlo nisku i vrlo visoku dimenziju reputacije: proizvodi i usluge postoji odstupanje, dodatno su formirani i sljedeći modeli kvantilne regresije: $10 \%, 25 \%, 50 \%$, $75 \%$ i $90 \%$. Na primjer, za model kvantilne regresije $10 \%$ provedena je regresijska analiza sa zavisnom binomnom varijablom, koja poprima vrijednosti: (a) 0 za $10 \%$ poduzeća koja imaju vrijednosti varijable dimenzija reputacije: proizvodi $i$ usluge manje od desetog percentila P10 i (b) 1 za $90 \%$ poduzeća koja imaju vrijednosti varijable.

Kao zavisna varijabla $\mathrm{u}$ ispitivanju hipoteze $\mathrm{H} 2$ korištena je skupna varijabla dimenzije reputacije vezane uz vodstvo VIZ_avg. Kao nezavisne varijable korištene su varijable kvalitete komuniciranja DOP-a putem mrežnih stranica i društvenih mreža. U modelima su također korištene i kontrolne varijable kojima se iskazuju karakteristike tržišta i poduzeća iz uzorka. Modelom linearne regresije hipoteza $\mathrm{H} 2$ testirana je na cijelom istraživačkom uzorku. Budući da je model linearne regresije pokazao kako kod poduzeća koja imaju vrlo nisku i vrlo visoku dimenziju reputacije: vodstvo postoji odstupanje, dodatno su formirani i sljedeći modeli kvantilne regresije: $10 \%, 25 \%, 50 \%, 75 \%$ i $90 \%$. Na primjer, za model kvantilne regresije $10 \%$ provedena je regresijska analiza sa zavisnom binomnom varijablom, koja poprima vrijednosti: (a) 0 za $10 \%$ poduzeća koja imaju vrijednosti varijable dimenzija reputacije: vodstvo manje od desetog percentila P10 i (b) 1 za $90 \%$ poduzeća koja imaju vrijednosti varijable.

Kao zavisna varijabla u ispitivanju hipoteze $\mathrm{H} 3$ korištena je skupna varijabla dimenzije reputacije vezane uz radne odnose RO_avg. Kao nezavisne varijable korištene su varijable kvalitete komuniciranja DOP-a putem mrežnih stranica i društvenih mreža. U modelima su također korištene i kontrolne varijable kojima se iskazuju karakteristike tržišta i poduzeća iz uzorka. Modelom linearne regresije hipoteza H1c testirana je na cijelom istraživačkom uzorku. Budući da je model linearne regresije pokazao kako kod poduzeća koja imaju vrlo nisku i vrlo visoku dimenziju reputacije: radni odnosi postoji odstupanje, dodatno su formirani i sljedeći modeli kvantilne regresije: $10 \%, 25 \%, 50 \%, 75 \%$ i $90 \%$. Na primjer, za model kvantilne regresije $10 \%$ provedena je regresijska analiza sa zavisnom binomnom varijablom, koja poprima vrijednosti: (a) 0 za $10 \%$ poduzeća koja imaju vrijednosti varijable dimenzija reputacije: radni odnosi manje od desetog percentila P10 i (b) 1 za $90 \%$ poduzeća koja imaju vrijednosti varijable.

\section{Karakteristike uzorka}

U prvom primarnom istraživanju sudjelovalo je 400 građana Republike Hrvatske u dobi od 18 do 65 godina, od čega 52,5 \% žena i 45,5\% muškaraca. U većini slučajeva ispitanici su zaposleni (39 \%), imaju do 25 godina ( $23 \%$ ) i srednju stručnu spremu (36 \%). Izražavajući stavove o reputaciji poduzeća, ispitanici su prosječno najbolje ocijenili varija- 
ble kvaliteta proizvoda i usluga $(4,364)$, vizija budućnosti $(4,264)$ i kvaliteta zaposlenika $(4,374)$.

Mrežne stranice hrvatskih poduzeća ocijenio je autor sukladno smjernicama GRI-ja. U istraživanju komunikacije društvene odgovornosti hrvatskih poduzeća putem mrežnih stranica najbolje su ocijenjene sljedeće dimenzije: dimenzija komuniciranja DOP-a - ravnoteža $(2,787)$, varijabla mrežne stranice iznose povoljne i nepovoljne rezultate i teme $(2,920)$, i dimenzija komuniciranja DOP-a - jasnoća $(2,783)$ varijable mrežna stranica izbjegava upotrebu tehničkih termina, skraćenica, žargona ili drugog sadržaja s kojima dionici vjerojatno nisu upoznati, te uključuje i obrazloženja (gdje je to potrebno) u relevantnim poglavljima ili u pojmovniku $(2,870)$ i podaci i informacije u izvješću dostupni su dionicima, uključujući i one dionike s posebnim potrebama u pogledu dostupnosti (na primjer, s obzirom na različite mogućnosti, jezike ili tehnologiju) $(2,870)$. Najslabiju prosječnu ocjenu ima dimenzija komuniciranja DOP-a - usporedivost $(1,984)$, varijabla mrežna stranica prikazuje Sektorske dodatke GRI-ja $(1,680)$.

\section{Rezultat istraživanja}

\section{Ispitivanje hipoteze $\mathrm{HI}$}

Tablica 3. prikazuje procjenu modela linearne regresije metodom najmanjih kvadrata; zavisna varijabla - dimenzija reputacije: proizvodi i usluge. Modelom je protumačeno 36,8 \% odstupanja. Nezavisne varijable kojima se mjeri kvaliteta komunikacije DOP-a korištenjem mrežnih stranica i društvenih mreža, a koje imaju statistički značajan utjecaj na zavisnu varijablu (dimenzija reputacije: proizvodi i usluge) su: PRAV_avg (pozitivan utjecaj uz $10 \%$ vjerojatnosti) i Facebook_da_ne (pozitivan utjecaj uz $5 \%$ vjerojatnosti). Kontrolne nezavisne varijable koje imaju statistički značajan utjecaj na zavisnu varijablu (dimenzija reputacije: proizvodi i usluge) su: rast tržišta (pozitivan utjecaj uz $5 \%$ ) i broj zaposlenih (negativan utjecaj uz $5 \%$ ).

Tablica 3. Procjena modela linearne regresije metodom najmanjih kvadrata; zavisna varijabla - dimenzija reputacije: proizvodi i usluge

\begin{tabular}{|c|c|c|c|c|c|}
\hline \multirow[t]{2}{*}{ Grupa nezavisnih varijabli } & $\begin{array}{c}\text { Nezavisne } \\
\text { varijable }\end{array}$ & B & $\begin{array}{l}\text { Std. } \\
\text { Error }\end{array}$ & $\mathbf{t}$ & Sig. \\
\hline & _cons & 3,010 & 0,535 & 5,631 & $0,000 * * *$ \\
\hline \multirow{6}{*}{$\begin{array}{l}\text { Kvaliteta komunikacije DOP-a } \\
\text { korištenjem mrežnih stranica }\end{array}$} & R_avg & 0,040 & 0,114 & 0,353 & 0,725 \\
\hline & U_avg & $-0,101$ & 0,132 & $-0,765$ & 0,447 \\
\hline & T_avg & $-0,188$ & 0,128 & $-1,466$ & 0,147 \\
\hline & PRAV_avg & 0,246 & 0,127 & 1,932 & $0,057 *$ \\
\hline & J_avg & $-0,079$ & 0,107 & $-0,740$ & 0,461 \\
\hline & POU_avg & 0,058 & 0,115 & 0,507 & 0,613 \\
\hline \multirow[t]{2}{*}{$\begin{array}{l}\text { Kvaliteta komunikacije DOP-a } \\
\text { korištenjem društvenih mreža }\end{array}$} & $\begin{array}{l}\text { Facebook_ } \\
\text { da_ne }\end{array}$ & 0,307 & 0,126 & 2,441 & $0,017 * *$ \\
\hline & $\begin{array}{l}\text { Twitter_da_ } \\
\text { ne }\end{array}$ & 0,097 & 0,135 & 0,722 & 0,473 \\
\hline
\end{tabular}




\begin{tabular}{|c|c|c|c|c|c|}
\hline \multirow[t]{2}{*}{ Grupa nezavisnih varijabli } & $\begin{array}{c}\text { Nezavisne } \\
\text { varijable }\end{array}$ & B & $\begin{array}{c}\text { Std. } \\
\text { Error }\end{array}$ & $\mathbf{t}$ & Sig. \\
\hline & _cons & 3,010 & $\mathbf{0 , 5 3 5}$ & 5,631 & $0,000 * * *$ \\
\hline \multicolumn{6}{|c|}{ Kontrolne varijable } \\
\hline $\begin{array}{l}\text { Kategorija kupca } \\
\text { (B2B nasuprot B2C-u) }\end{array}$ & Kat_kupca & $-0,075$ & 0,144 & $-0,519$ & 0,605 \\
\hline Rast tržišta & Rast_tržišta & 0,231 & 0,113 & 2,031 & $0,045 * *$ \\
\hline Opseg tržišta & $\begin{array}{l}\text { Opseg } \\
\text { tržišta }\end{array}$ & 0,172 & 0,134 & 1,283 & 0,203 \\
\hline Intenzitet konkurentnosti tržišta & Intenz_konk & 0,086 & 0,110 & 0,785 & 0,435 \\
\hline \multirow[t]{2}{*}{ Veličina poduzeća } & Br_zap & 0,000 & 0,000 & $-2,275$ & $0,026^{* *}$ \\
\hline & Uk_prih & 0,000 & 0,000 & $-0,321$ & 0,749 \\
\hline Djelatnost & $\begin{array}{l}\text { Djelatnost_ } \\
\text { kod }\end{array}$ & 0,008 & 0,084 & 0,095 & 0,924 \\
\hline Privatno i javno vlasništvo & $\begin{array}{l}l_{\text {Privatno_ }} \\
\text { javno }\end{array}$ & 0,022 & 0,175 & 0,124 & 0,901 \\
\hline Domaće i strano vlasništvo & $\begin{array}{l}\text { Domaće_ } \\
\text { strano }\end{array}$ & $-0,046$ & 0,132 & $-0,344$ & 0,731 \\
\hline \multicolumn{6}{|l|}{ Regresijska dijagnostika } \\
\hline R Square & & & & & 0,509 \\
\hline Adjusted R Square & & & & & 0,368 \\
\hline
\end{tabular}

Izvor: autorski rad

Napomena: *** statistički značajno uz $1 \%$ vjerojatnosti, ** $5 \%$ vjerojatnosti, * $10 \%$ vjerojatnosti

Tablica 4. prikazuje procjenu kvantilne regresije; zavisna varijabla - dimenzija reputacije: proizvodi i usluge - $10 \%$ percentil. Modelom je protumačeno 37,7 \% odstupanja. Nezavisne varijable kojima se mjeri kvaliteta komunikacije DOP-a korištenjem mrežnih stranica i društvenih mreža, a koje imaju statistički značajan utjecaj na zavisnu varijablu (dimenzija reputacije: proizvodi i usluge) su: U_avg i T_avg (negativan utjecaj uz $1 \%$ vjerojatnosti), PRAV_avg i POU_avg (pozitivan utjecaj uz $1 \%$ vjerojatnosti) i J_avg (negativan utjecaj uz $5 \%$ vjerojatnosti). Kontrolne nezavisne varijable koje imaju statistički značajan utjecaj na zavisnu varijablu (dimenzija reputacije: proizvodi i usluge) su: rast tržišta i intenzitet konkurentnosti tržišta (pozitivan utjecaj uz $1 \%$ ), broj zaposlenih (negativan utjecaj uz $1 \%$ ) i ukupan prihod (negativan utjecaj uz $5 \%$ ). 
Tablica 4. Procjena modela kvantilne regresije; zavisna varijabla - dimenzija reputacije: proizvodi i usluge - $10 \%$ percentil

\begin{tabular}{|c|c|c|c|c|c|}
\hline \multirow[t]{2}{*}{ Grupa nezavisnih varijabli } & $\begin{array}{c}\text { Nezavisne } \\
\text { varijable }\end{array}$ & B & \begin{tabular}{|c|} 
Std. \\
Error
\end{tabular} & $\mathbf{t}$ & Sig. \\
\hline & _cons & 2,713 & 0,300 & 9,030 & $0,000 * * *$ \\
\hline \multirow{6}{*}{$\begin{array}{l}\text { Kvaliteta komunikacije DOP-a } \\
\text { korištenjem mrežnih stranica }\end{array}$} & R_avg & 0,079 & 0,064 & 1,230 & 0,223 \\
\hline & U_avg & $-0,248$ & 0,074 & $-3,350$ & $0,001 * * *$ \\
\hline & T_avg & $-0,264$ & 0,072 & $-3,660$ & $0,000 * * *$ \\
\hline & \begin{tabular}{|l|} 
PRAV_avg \\
\end{tabular} & 0,223 & 0,072 & 3,110 & 0,003 *** \\
\hline & J_avg & $-0,156$ & 0,060 & $-2,590$ & $0,011 * *$ \\
\hline & POU_avg & 0,327 & 0,064 & 5,070 & $0,000 * * *$ \\
\hline \multirow[t]{2}{*}{$\begin{array}{l}\text { Kvaliteta komunikacije DOP-a } \\
\text { korištenjem društvenih mreža }\end{array}$} & $\begin{array}{l}\text { Facebook_ } \\
\text { da_ne }\end{array}$ & 0,080 & 0,071 & 1,140 & 0,259 \\
\hline & $\begin{array}{l}\text { Twitter_da_ } \\
\text { ne }\end{array}$ & 0,084 & 0,076 & 1,110 & 0,269 \\
\hline \multicolumn{6}{|l|}{ Kontrolne varijable } \\
\hline $\begin{array}{l}\text { Kategorija kupca } \\
\text { (B2B nasuprot B2C-u) }\end{array}$ & Kat_kupca & 0,010 & 0,081 & 0,130 & 0,897 \\
\hline Rast tržišta & Rast_tržišta & 0,262 & 0,064 & 4,110 & $0,000 * * *$ \\
\hline Opseg tržišta & Opseg_tržišta & $-0,041$ & 0,075 & $-0,540$ & 0,588 \\
\hline Intenzitet konkurentnosti tržišta & Intenz_konk & 0,219 & 0,062 & 3,540 & $0,001 * * *$ \\
\hline \multirow[t]{2}{*}{ Veličina poduzeća } & Br_zap & 0,000 & 0,000 & $-6,460$ & $0,000 * * *$ \\
\hline & Uk_prih & 0,000 & 0,000 & $-2,240$ & $0,028 * *$ \\
\hline Djelatnost & $\begin{array}{l}\text { Djelatnost__ } \\
\text { kod }\end{array}$ & $-0,055$ & 0,047 & $-1,160$ & 0,251 \\
\hline Privatno i javno vlasništvo & $\begin{array}{l}\text { Privatno_ } \\
\text { javno }\end{array}$ & 0,039 & 0,098 & 0,400 & 0,692 \\
\hline Domaće i strano vlasništvo & $\begin{array}{l}\text { Domaće_ } \\
\text { strano }\end{array}$ & 0,106 & 0,074 & 1,430 & 0,156 \\
\hline \multicolumn{6}{|l|}{ Regresijska dijagnostika } \\
\hline Pseudo R Square & & & & & 0,377 \\
\hline
\end{tabular}

Napomena: $* * *$ statistički značajno uz $1 \%$ vjerojatnosti, $* * 5 \%$ vjerojatnosti, * $10 \%$ vjerojatnosti Izvor: autorski rad

Tablica 5. prikazuje procjenu kvantilne regresije; zavisna varijabla - dimenzija reputacije: proizvodi i usluge $-25 \%$ percentil. Modelom je protumačeno 27,6 \% odstupanja. Nezavisne varijable kojima se mjeri kvaliteta komunikacije DOP-a korištenjem mrežnih stranica i društvenih mreža, a koje imaju statistički značajan utjecaj na zavisnu varijablu (dimenzija reputacije: proizvodi i usluge) su: PRAV_avg (pozitivan utjecaj uz $10 \%$ vjerojatnosti) i Facebook_da_ne (pozitivan utjecaj uz $5 \%$ vjerojatnosti). Kontrolne nezavisne varijable koje imaju statistički značajan utjecaj na zavisnu varijablu (dimenzija reputacije: proizvodi i usluge) su: opseg tržišta (pozitivan utjecaj uz $10 \%$ ), intenzitet konkurentnosti tržišta (pozitivan utjecaj uz 5 \%) i broj zaposlenih (negativan utjecaj uz $5 \%$ ). 
Tablica 5. Procjena modela kvantilne regresije; zavisna varijabla - dimenzija reputacije: proizvodi i usluge $-25 \%$ percentil

\begin{tabular}{|c|c|c|c|c|c|}
\hline \multirow[t]{2}{*}{ Grupa nezavisnih varijabli } & $\begin{array}{c}\text { Nezavisne } \\
\text { varijable }\end{array}$ & B & \begin{tabular}{|c|} 
Std. \\
Error \\
\end{tabular} & $\mathbf{t}$ & Sig. \\
\hline & _cons & 2,480 & 0,536 & 4,630 & $0,000 * * *$ \\
\hline \multirow{6}{*}{$\begin{array}{l}\text { Kvaliteta komunikacije DOP-a } \\
\text { korištenjem mrežnih stranica }\end{array}$} & R_avg & 0,057 & 0,115 & 0,500 & 0,617 \\
\hline & U_avg & $-0,209$ & 0,132 & $-1,580$ & 0,117 \\
\hline & T_avg & 0,015 & 0,128 & 0,120 & 0,908 \\
\hline & PRAV_avg & 0,220 & 0,128 & 1,730 & $0,088 *$ \\
\hline & J_avg & $-0,159$ & 0,107 & $-1,480$ & 0,142 \\
\hline & POU_avg & 0,065 & 0,115 & 0,560 & 0,575 \\
\hline \multirow[t]{2}{*}{$\begin{array}{l}\text { Kvaliteta komunikacije DOP-a } \\
\text { korištenjem društvenih mreža }\end{array}$} & $\begin{array}{l}\text { Facebook_- } \\
\text { da_ne }\end{array}$ & 0,265 & 0,126 & 2,100 & $0,039 * *$ \\
\hline & $\begin{array}{l}\text { Twitter_da_ } \\
\text { ne }\end{array}$ & 0,028 & 0,135 & 0,210 & 0,836 \\
\hline \multicolumn{6}{|c|}{ Kontrolne varijable } \\
\hline $\begin{array}{l}\text { Kategorija kupca (B2B nasuprot } \\
\text { B2C-u) }\end{array}$ & Kat_kupca & 0,046 & 0,145 & 0,320 & 0,751 \\
\hline Rast tržišta & Rast_tržišta & 0,054 & 0,114 & 0,470 & 0,636 \\
\hline Opseg tržišta & Opseg_tržišta & 0,232 & 0,134 & 1,730 & $0,088 *$ \\
\hline Intenzitet konkurentnosti tržišta & Intenz_konk & 0,236 & 0,110 & 2,150 & $0,035 * *$ \\
\hline \multirow[t]{2}{*}{ Veličina poduzeća } & Br_zap & 0,000 & 0,000 & $-2,200$ & $0,031 * *$ \\
\hline & Uk_prih & 0,000 & 0,000 & $-0,040$ & 0,968 \\
\hline Djelatnost & $\begin{array}{l}\text { Djelatnost__ } \\
\text { kod }\end{array}$ & $-0,046$ & 0,085 & $-0,550$ & 0,585 \\
\hline Privatno i javno vlasništvo & $\begin{array}{l}\text { Privatno_ } \\
\text { javno }\end{array}$ & 0,050 & 0,175 & 0,280 & 0,778 \\
\hline Domaće i strano vlasništvo & $\begin{array}{l}\text { Domaće_ } \\
\text { strano }\end{array}$ & 0,062 & 0,132 & 0,470 & 0,639 \\
\hline \multicolumn{6}{|l|}{ Regresijska dijagnostika } \\
\hline Pseudo R Square & & & & & 0,276 \\
\hline
\end{tabular}

Izvor: autorski rad

Napomena: *** statistički značajno uz $1 \%$ vjerojatnosti, $* * 5 \%$ vjerojatnosti, $* 10 \%$ vjerojatnosti

Tablica 6. prikazuje procjenu kvantilne regresije; zavisna varijabla - dimenzija reputacije: proizvodi i usluge - $50 \%$ percentil. Modelom je protumačeno 25,5\% odstupanja. Nezavisna varijabla kojom se mjeri kvaliteta komunikacije DOP-a korištenjem društvenih mreža, a koja ima statistički značajan utjecaj na zavisnu varijablu (dimenzija reputacije: proizvodi i usluge) je Facebook_da_ne (pozitivan utjecaj uz 1 \% vjerojatnosti). Kontrolna nezavisna varijabla koja ima statistički značajan utjecaj na zavisnu varijablu (dimenzija reputacije: proizvodi i usluge) je opseg tržišta (pozitivan utjecaj uz $10 \%$ ). 
Tablica 6. Procjena modela kvantilne regresije; zavisna varijabla - dimenzija reputacije: proizvodi i usluge $-50 \%$ percentil

\begin{tabular}{|c|c|c|c|c|c|}
\hline \multirow[t]{2}{*}{ Grupa nezavisnih varijabli } & $\begin{array}{c}\text { Nezavisne } \\
\text { varijable }\end{array}$ & B & $\begin{array}{l}\text { Std. } \\
\text { Error }\end{array}$ & $\mathbf{t}$ & Sig. \\
\hline & _cons & 2,843 & 0,769 & 3,690 & $0,000 * * *$ \\
\hline \multirow{6}{*}{$\begin{array}{l}\text { Kvaliteta komunikacije DOP-a } \\
\text { korištenjem mrežnih stranica }\end{array}$} & R_avg & 0,019 & 0,165 & 0,120 & 0,907 \\
\hline & U_avg & $-0,080$ & 0,190 & $-0,420$ & 0,674 \\
\hline & T_avg & $-0,073$ & 0,185 & $-0,400$ & 0,692 \\
\hline & PRAV_avg & 0,279 & 0,183 & 1,520 & 0,133 \\
\hline & J_avg & $-0,142$ & 0,154 & $-0,920$ & 0,359 \\
\hline & POU_avg & $-0,040$ & 0,165 & $-0,240$ & 0,808 \\
\hline \multirow[t]{2}{*}{$\begin{array}{l}\text { Kvaliteta komunikacije DOP-a } \\
\text { korištenjem društvenih mreža }\end{array}$} & $\begin{array}{l}\text { Facebook_ } \\
\text { da_ne }\end{array}$ & 0,502 & 0,181 & 2,770 & $0,007 * * *$ \\
\hline & $\begin{array}{l}\text { Twitter_da_ } \\
\text { ne }\end{array}$ & 0,084 & 0,194 & 0,430 & 0,667 \\
\hline \multicolumn{6}{|c|}{ Kontrolne varijable } \\
\hline $\begin{array}{l}\text { Kategorija kupca } \\
\text { (B2B nasuprot B2C-u) }\end{array}$ & Kat_kupca & $-0,070$ & 0,208 & $-0,340$ & 0,737 \\
\hline Rast tržišta & Rast_tržišta & 0,104 & 0,163 & 0,640 & 0,526 \\
\hline Opseg tržišta & Opseg_tržišta & 0,345 & 0,193 & 1,790 & 0,077 * \\
\hline Intenzitet konkurentnosti tržišta & Intenz_konk & 0,039 & 0,158 & 0,250 & 0,807 \\
\hline \multirow[t]{2}{*}{ Veličina poduzeća } & Br_zap & 0,000 & 0,000 & $-1,460$ & 0,149 \\
\hline & Uk_prih & 0,000 & 0,000 & $-0,770$ & 0,445 \\
\hline Djelatnost & $\begin{array}{l}\text { Djelatnost__ } \\
\text { kod }\end{array}$ & $-0,001$ & 0,122 & $-0,010$ & 0,995 \\
\hline Privatno i javno vlasništvo & $\begin{array}{l}\text { Privatno_ } \\
\text { javno }\end{array}$ & 0,127 & 0,252 & 0,500 & 0,617 \\
\hline Domaće i strano vlasništvo & \begin{tabular}{|l} 
Domaće_ \\
strano
\end{tabular} & $-0,072$ & 0,190 & $-0,380$ & 0,704 \\
\hline \multicolumn{6}{|l|}{ Regresijska dijagnostika } \\
\hline Pseudo R Square & & & & & 0,255 \\
\hline
\end{tabular}

Izvor: autorski rad

Napomena: *** statistički značajno uz $1 \%$ vjerojatnosti, $* * 5 \%$ vjerojatnosti, $* 10 \%$ vjerojatnosti

Tablica 7. prikazuje procjenu kvantilne regresije; zavisna varijabla - dimenzija reputacije: proizvodi i usluge - $75 \%$ percentil. Modelom je protumačeno $33,3 \%$ odstupanja. Nezavisna varijabla kojom se mjeri kvaliteta komunikacije DOP-a korištenjem društvenih mreža, a koja ima statistički značajan utjecaj na zavisnu varijablu (dimenzija reputacije: proizvodi i usluge) je Facebook_da_ne (pozitivan utjecaj uz 1 \% vjerojatnosti). Kontrolne nezavisne varijable koje imaju statistički značajan utjecaj na zavisnu varijablu (dimenzija reputacije: proizvodi i usluge) su: opseg tržišta (pozitivan utjecaj uz 5 \%) i rast tržišta (pozitivan utjecaj uz $10 \%$ ). 
Tablica 7. Procjena modela kvantilne regresije; zavisna varijabla - dimenzija reputacije: proizvodi i usluge $-75 \%$ percentil

\begin{tabular}{|c|c|c|c|c|c|}
\hline \multirow[t]{2}{*}{ Nezavisne varijable } & $\begin{array}{c}\text { Nezavisne } \\
\text { varijable }\end{array}$ & B & \begin{tabular}{|c|} 
Std. \\
Error
\end{tabular} & $\mathbf{t}$ & Sig. \\
\hline & _cons & 2,940 & $\mathbf{0 , 5 5 0}$ & 5,350 & $0,000 * * *$ \\
\hline \multirow{6}{*}{$\begin{array}{l}\text { Kvaliteta komunikacije DOP-a } \\
\text { korištenjem mrežnih stranica }\end{array}$} & R_avg & $-0,022$ & 0,118 & $-0,190$ & 0,853 \\
\hline & U_avg & 0,077 & 0,135 & 0,570 & 0,571 \\
\hline & T_avg & $-0,120$ & 0,132 & $-0,910$ & 0,364 \\
\hline & PRAV_avg & 0,206 & 0,131 & 1,570 & 0,119 \\
\hline & J_avg & 0,017 & 0,110 & 0,150 & 0,878 \\
\hline & POU_avg & $-0,178$ & 0,118 & $-1,510$ & 0,135 \\
\hline \multirow[t]{2}{*}{$\begin{array}{l}\text { Kvaliteta komunikacije DOP-a } \\
\text { korištenjem društvenih mreža }\end{array}$} & $\begin{array}{l}\text { Facebook_ } \\
\text { da_ne }\end{array}$ & 0,552 & 0,129 & 4,270 & $0,000 * * *$ \\
\hline & $\begin{array}{l}\text { Twitter_da_ } \\
\text { ne }\end{array}$ & 0,105 & 0,139 & 0,760 & 0,452 \\
\hline \multicolumn{6}{|c|}{ Kontrolne varijable } \\
\hline $\begin{array}{l}\text { Kategorija kupca (B2B nasuprot } \\
\text { B2C-u) }\end{array}$ & Kat_kupca & $-0,219$ & 0,148 & $-1,480$ & 0,143 \\
\hline Rast tržišta & Rast_tržišta & 0,201 & 0,117 & 1,720 & $0,089 *$ \\
\hline Opseg tržišta & Opseg_tržišta & 0,327 & 0,138 & 2,380 & $0,020 * *$ \\
\hline Intenzitet konkurentnosti tržišta & Intenz_konk & $-0,017$ & 0,113 & $-0,150$ & 0,878 \\
\hline \multirow[t]{2}{*}{ Veličina poduzeća } & Br_zap & 0,000 & 0,000 & $-0,110$ & 0,911 \\
\hline & Uk_prih & 0,000 & 0,000 & $-1,500$ & 0,137 \\
\hline Djelatnost & $\begin{array}{l}\text { Djelatnost_ } \\
\text { kod }\end{array}$ & 0,077 & 0,087 & 0,890 & 0,376 \\
\hline Privatno i javno vlasništvo & \begin{tabular}{|l|}
$\begin{array}{l}\text { Privatno_ } \\
\text { javno }\end{array}$ \\
\end{tabular} & 0,124 & 0,180 & 0,690 & 0,492 \\
\hline Domaće i strano vlasništvo & $\begin{array}{l}\begin{array}{l}\text { Domaće } \\
\text { strano }\end{array} \\
\end{array}$ & $-0,088$ & 0,136 & $-0,650$ & 0,520 \\
\hline \multicolumn{6}{|l|}{ Regresijska dijagnostika } \\
\hline Pseudo R Square & & & & & 0,333 \\
\hline
\end{tabular}

Izvor: autorski rad

Napomena: *** statistički značajno uz $1 \%$ vjerojatnosti, $* * 5 \%$ vjerojatnosti, $* 10 \%$ vjerojatnosti

Tablica 8. prikazuje procjenu kvantilne regresije; zavisna varijabla - dimenzija reputacije: proizvodi i usluge - $90 \%$ percentil. Modelom je protumačeno 38,8 \% odstupanja. Nezavisna varijabla kojom se mjeri kvaliteta komunikacije DOP-a korištenjem društvenih mreža, a koja ima statistički značajan utjecaj na zavisnu varijablu (dimenzija reputacije: proizvodi i usluge) je Facebook_da_ne (pozitivan utjecaj uz 1 \% vjerojatnosti). Kontrolne nezavisne varijable koje imaju statistički značajan utjecaj na zavisnu varijablu (dimenzija reputacije: proizvodi i usluge) su: rast tržišta (pozitivan utjecaj uz $1 \%$ ) i djelatnost (pozitivan utjecaj uz $5 \%$ ). 
Tablica 8. Procjena modela kvantilne regresije; zavisna varijabla - dimenzija reputacije: proizvodi i usluge - $90 \%$ percentil

\begin{tabular}{|c|c|c|c|c|c|}
\hline \multirow[t]{2}{*}{ Grupa nezavisnih varijabli } & $\begin{array}{c}\text { Nezavisne } \\
\text { varijable }\end{array}$ & B & \begin{tabular}{|l|} 
Std. \\
Error
\end{tabular} & $\mathbf{t}$ & Sig. \\
\hline & _cons & 3,265 & 0,548 & 5,960 & $0,000 * * *$ \\
\hline \multirow{6}{*}{$\begin{array}{l}\text { Kvaliteta komunikacije DOP-a } \\
\text { korištenjem mrežnih stranica }\end{array}$} & R_avg & 0,091 & 0,117 & 0,780 & 0,439 \\
\hline & U_avg & 0,091 & 0,135 & 0,670 & 0,502 \\
\hline & T_avg & $-0,164$ & 0,131 & $-1,250$ & 0,214 \\
\hline & PRAV_avg & 0,201 & 0,131 & 1,540 & 0,128 \\
\hline & J_avg & $-0,085$ & 0,110 & $-0,770$ & 0,443 \\
\hline & POU_avg & $-0,187$ & 0,118 & $-1,590$ & 0,115 \\
\hline \multirow[t]{2}{*}{$\begin{array}{l}\text { Kvaliteta komunikacije DOP-a } \\
\text { korištenjem društvenih mreža }\end{array}$} & $\begin{array}{l}\text { Facebook_ } \\
\text { da_ne }\end{array}$ & 0,403 & 0,129 & 3,130 & $0,002 * * *$ \\
\hline & Twitter_da_ne & 0,177 & 0,138 & 1,280 & 0,204 \\
\hline \multicolumn{6}{|c|}{ Kontrolne varijable } \\
\hline $\begin{array}{l}\text { Kategorija kupca } \\
\text { (B2B nasuprot B2C-u) }\end{array}$ & Kat_kupca & $-0,149$ & 0,148 & $-1,010$ & 0,315 \\
\hline Rast tržišta & Rast_tržišta & 0,395 & 0,116 & 3,400 & $0,001 * * *$ \\
\hline Opseg tržišta & Opseg_tržišta & 0,135 & 0,137 & 0,980 & 0,328 \\
\hline Intenzitet konkurentnosti tržišta & Intenz_konk & $-0,174$ & 0,112 & $-1,540$ & 0,126 \\
\hline \multirow[t]{2}{*}{ Veličina poduzeća } & Br_zap & 0,000 & 0,000 & $-1,220$ & 0,228 \\
\hline & Uk_prih & 0,000 & 0,000 & $-1,490$ & 0,140 \\
\hline Djelatnost & $\begin{array}{l}\text { Djelatnost_ } \\
\text { kod }\end{array}$ & 0,202 & 0,086 & 2,340 & $0,022 * *$ \\
\hline Privatno i javno vlasništvo & $\begin{array}{l}\text { Privatno } \\
\text { javno }\end{array}$ & $-0,093$ & 0,179 & $-0,520$ & 0,607 \\
\hline Domaće i strano vlasništvo & $\begin{array}{l}\text { Domaće } \\
\text { strano }\end{array}$ & 0,112 & 0,135 & 0,830 & 0,410 \\
\hline \multicolumn{6}{|l|}{ Regresijska dijagnostika } \\
\hline Pseudo R Square & & & & & 0,388 \\
\hline
\end{tabular}

Izvor: autorski rad

Napomena: *** statistički značajno uz $1 \%$ vjerojatnosti, ** $5 \%$ vjerojatnosti, * $10 \%$ vjerojatnosti

\section{Ispitivanje hipoteze $\mathrm{H} 2$}

Tablica 9. prikazuje procjenu modela linearne regresije metodom najmanjih kvadrata; zavisna varijabla - dimenzija reputacije: vodstvo. Modelom je protumačeno 36,2 \% odstupanja. Nezavisne varijable kojima se mjeri kvaliteta komunikacije DOP-a korištenjem mrežnih stranica i društvenih mreža, a koje imaju statistički značajan utjecaj na zavisnu varijablu (dimenzija reputacije: vodstvo) su: PRAV_avg (pozitivan utjecaj uz $5 \%$ vjerojatnosti) i Facebook_da_ne (pozitivan utjecaj uz $5 \%$ vjerojatnosti). Kontrolne nezavisne varijable koje imaju statistički značajan utjecaj na zavisnu varijablu (dimenzija reputacije: vodstvo) su: Rast tržišta (pozitivan utjecaj uz $1 \%$ ) i Broj zaposlenih (negativan utjecaj uz 5 \%). 
$\underline{\text { I. Klopotan: Povezanost kvalitete online komuniciranja društveno odgovornog poslovanja i reputacije... }}$

Tablica 9. Procjena modela linearne regresije metodom najmanjih kvadrata; zavisna varijabla - dimenzija reputacije: vodstvo

\begin{tabular}{|c|c|c|c|c|c|c|}
\hline \multirow{2}{*}{$\begin{array}{c}\text { Grupa nezavisnih } \\
\text { varijabli }\end{array}$} & $\begin{array}{l}\text { Nezavisne } \\
\text { varijable }\end{array}$ & B & $\begin{array}{c}\text { Std. } \\
\text { Error }\end{array}$ & $\mathbf{t}$ & Sig. & VIF \\
\hline & (Constant) & 2,566 & 0,609 & 4,213 & $0,000 * * *$ & \\
\hline \multirow{6}{*}{$\begin{array}{l}\text { Kvaliteta komunikacije } \\
\text { DOP-a korištenjem } \\
\text { mrežnih stranica }\end{array}$} & R_avg & 0,091 & 0,130 & 0,700 & 0,486 & 14,960 \\
\hline & U_avg & $-0,057$ & 0,150 & $-0,381$ & 0,704 & 14,897 \\
\hline & T_avg & $-0,209$ & 0,146 & $-1,432$ & 0,156 & 16,907 \\
\hline & PRAV_avg & 0,303 & 0,145 & 2,085 & $0,040^{* * *}$ & 16,432 \\
\hline & J_avg & $-0,169$ & 0,122 & $-1,389$ & 0,169 & 12,862 \\
\hline & POU_avg & 0,029 & 0,131 & 0,224 & 0,823 & 11,630 \\
\hline \multirow{2}{*}{$\begin{array}{l}\text { Kvaliteta komunikacije } \\
\text { DOP-a korištenjem } \\
\text { društvenih mreža }\end{array}$} & $\begin{array}{l}\text { Facebook_ } \\
\text { da_ne }\end{array}$ & 0,364 & 0,143 & 2,545 & $0,013 * *$ & 1,492 \\
\hline & $\begin{array}{l}\text { Twitter_da } \\
\text { ne }\end{array}$ & 0,102 & 0,154 & 0,665 & 0,508 & 1,592 \\
\hline \multicolumn{7}{|c|}{ Kontrolne varijable } \\
\hline $\begin{array}{l}\text { Kategorija kupca (B2B } \\
\text { nasuprot B2C-u) }\end{array}$ & Kat_kupca & $-0,116$ & 0,164 & $-0,708$ & 0,481 & 1,968 \\
\hline Rast tržišta & Rast_tržišta & 0,400 & 0,129 & 3,090 & $0,003 * * *$ & 1,766 \\
\hline Opseg tržišta & Opseg_tržišta & 0,010 & 0,153 & 0,063 & 0,950 & 2,570 \\
\hline $\begin{array}{l}\text { Intenzitet konkurentnosti } \\
\text { tržišta }\end{array}$ & Intenz_konk & 0,078 & 0,125 & 0,622 & 0,535 & 2,225 \\
\hline \multirow[t]{2}{*}{ Veličina poduzeća } & Br_zap & 0,000 & 0,000 & $-2,403$ & $0,019 * *$ & 1,781 \\
\hline & Uk_prih & 0,000 & 0,000 & 0,422 & 0,674 & 1,729 \\
\hline Djelatnost & $\begin{array}{l}\text { Djelatnost_ } \\
\text { kod }\end{array}$ & 0,149 & 0,096 & 1,552 & 0,124 & 1,764 \\
\hline $\begin{array}{l}\text { Privatno i javno } \\
\text { vlasništvo }\end{array}$ & $\begin{array}{l}\text { Privatno_ } \\
\text { javno }\end{array}$ & $-0,153$ & 0,200 & $-0,767$ & 0,445 & 2,050 \\
\hline $\begin{array}{l}\text { Domaće i strano } \\
\text { vlasništvo }\end{array}$ & $\begin{array}{l}\begin{array}{l}\text { Domaće } \\
\text { strano }\end{array} \\
\end{array}$ & 0,201 & 0,151 & 1,334 & 0,186 & 1,621 \\
\hline \multicolumn{7}{|l|}{ Regresijska dijagnostika } \\
\hline R Square & & & & & & 0,472 \\
\hline Adjusted R Square & & & & & & 0,362 \\
\hline Durbin-Watson & & & & & & 1,081 \\
\hline
\end{tabular}

Izvor: autorski rad

Napomena: *** statistički značajno uz $1 \%$ vjerojatnosti, ** $5 \%$ vjerojatnosti, * $10 \%$ vjerojatnosti

Tablica 10. prikazuje procjenu kvantilne regresije; zavisna varijabla - dimenzija reputacije: vodstvo - $10 \%$ percentil. Modelom je protumačeno 39,4\% odstupanja. Nezavisne varijable kojima se mjeri kvaliteta komunikacije DOP-a korištenjem mrežnih stranica i društvenih mreža, a koje imaju statistički značajan utjecaj na zavisnu varijablu (dimenzija reputacije: vodstvo) su: U_avg (negativan utjecaj uz 1 vjerojatnosti), J_avg (negativan utjecaj uz $10 \%$ vjerojatnosti), PRAV_avg i Facebook_da_ne (pozitivan utjecaj uz $5 \%$ vjero- 
jatnosti) i POU_avg (pozitivan utjecaj uz $1 \%$ vjerojatnosti). Kontrolne nezavisne varijable koje imaju statistički značajan utjecaj na zavisnu varijablu (dimenzija reputacije: vodstvo) su: rast tržišta (pozitivan utjecaj uz $10 \%$ ), intenzitet konkurentnosti tržišta (pozitivan utjecaj uz $5 \%$ ) i broj zaposlenih (negativan utjecaj uz $1 \%$ ).

Tablica 10. Procjena modela kvantilne regresije; zavisna varijabla - dimenzija reputacije: vodstvo - $10 \%$ percentil

\begin{tabular}{|c|c|c|c|c|c|}
\hline \multirow[t]{2}{*}{ Grupa nezavisnih varijabli } & $\begin{array}{c}\text { Nezavisne } \\
\text { varijable }\end{array}$ & B & $\begin{array}{l}\text { Std. } \\
\text { Error }\end{array}$ & $\mathbf{t}$ & Sig. \\
\hline & _cons & 2,148 & 0,630 & 3,410 & $0,001 * * *$ \\
\hline \multirow{6}{*}{$\begin{array}{l}\text { Kvaliteta komunikacije DOP-a } \\
\text { korištenjem mrežnih stranica }\end{array}$} & R_avg & 0,148 & 0,135 & 1,100 & 0,274 \\
\hline & U_avg & $-0,521$ & 0,155 & $-3,360$ & $0,001 * * *$ \\
\hline & T_avg & $-0,139$ & 0,151 & $-0,920$ & 0,359 \\
\hline & PRAV_avg & 0,339 & 0,150 & 2,260 & $0,026^{* *}$ \\
\hline & J_avg & $-0,217$ & 0,126 & $-1,720$ & $0,089 *$ \\
\hline & POU_avg & 0,381 & 0,135 & 2,820 & $0,006 * * *$ \\
\hline \multirow[t]{2}{*}{$\begin{array}{l}\text { Kvaliteta komunikacije DOP-a } \\
\text { korištenjem društvenih mreža }\end{array}$} & $\begin{array}{l}\text { Facebook_ } \\
\text { da_ne }\end{array}$ & 0,336 & 0,148 & 2,270 & $0,026^{* *}$ \\
\hline & $\begin{array}{l}\text { Twitter_da_ } \\
\text { ne }\end{array}$ & 0,162 & 0,159 & 1,020 & 0,312 \\
\hline \multicolumn{6}{|c|}{ Kontrolne varijable } \\
\hline $\begin{array}{l}\text { Kategorija kupca } \\
\text { (B2B nasuprot B2C-u) }\end{array}$ & Kat_kupca & 0,174 & 0,170 & 1,020 & 0,309 \\
\hline Rast tržišta & Rast_tržišta & 0,240 & 0,134 & 1,790 & $0,077 *$ \\
\hline Opseg tržišta & Opseg_tržišta & $-0,052$ & 0,158 & $-0,330$ & 0,741 \\
\hline Intenzitet konkurentnosti tržišta & Intenz_konk & 0,302 & 0,129 & 2,340 & $0,022 * *$ \\
\hline \multirow[t]{2}{*}{ Veličina poduzeća } & Br_zap & 0,000 & 0,000 & $-4,390$ & $0,000 * * *$ \\
\hline & Uk_prih & 0,000 & 0,000 & 0,540 & 0,591 \\
\hline Djelatnost & $\begin{array}{l}\text { Djelatnost_ } \\
\text { kod }\end{array}$ & 0,130 & 0,099 & 1,300 & 0,196 \\
\hline Privatno i javno vlasništvo & $\begin{array}{l}\text { Privatno_ } \\
\text { javno }\end{array}$ & $-0,320$ & 0,206 & $-1,550$ & 0,124 \\
\hline Domaće i strano vlasništvo & $\begin{array}{l}\text { Domaće } \\
\text { strano }\end{array}$ & 0,033 & 0,156 & 0,210 & 0,831 \\
\hline \multicolumn{6}{|l|}{ Regresijska dijagnostika } \\
\hline Pseudo R Square & & & & & 0,394 \\
\hline
\end{tabular}

Izvor: autorski rad

Napomena: *** statistički značajno uz $1 \%$ vjerojatnosti, ** $5 \%$ vjerojatnosti, * $10 \%$ vjerojatnosti

Tablica 11. prikazuje procjenu kvantilne regresije; zavisna varijabla - dimenzija reputacije: vodstvo $-25 \%$ percentil. Modelom je protumačeno 34,4 \% odstupanja. Nezavisne varijable kojima se mjeri kvaliteta komunikacije DOP-a korištenjem mrežnih stranica, a koje imaju statistički značajan utjecaj na zavisnu varijablu (dimenzija reputacije: vodstvo) 
su: PRAV_avg (pozitivan utjecaj uz $1 \%$ vjerojatnosti) i J_avg (negativan utjecaj uz $10 \%$ vjerojatnosti). Kontrolne nezavisne varijable koje imaju statistički značajan utjecaj na zavisnu varijablu (dimenzija reputacije: vodstvo) su: rast tržišta (pozitivan utjecaj uz 5 \%) i broj zaposlenih (negativan utjecaj uz $1 \%$ ).

Tablica 11. Procjena modela kvantilne regresije; zavisna varijabla - dimenzija reputacije: vodstvo - $25 \%$ percentil

\begin{tabular}{|c|c|c|c|c|c|}
\hline \multirow{2}{*}{ Grupa nezavisnih varijabli } & $\begin{array}{c}\text { Nezavisne } \\
\text { varijable }\end{array}$ & B & $\begin{array}{l}\text { Std. } \\
\text { Error }\end{array}$ & $\mathbf{t}$ & Sig. \\
\hline & _cons & 1,980 & 0,735 & 2,690 & $0,009 * * *$ \\
\hline \multirow{6}{*}{$\begin{array}{l}\text { Kvaliteta komunikacije DOP-a } \\
\text { korištenjem mrežnih stranica }\end{array}$} & R_avg & 0,030 & 0,157 & 0,190 & 0,850 \\
\hline & U_avg & $-0,246$ & 0,181 & $-1,360$ & 0,178 \\
\hline & T_avg & $-0,004$ & 0,176 & $-0,020$ & 0,984 \\
\hline & PRAV_avg & 0,478 & 0,175 & 2,730 & $0,008 * * *$ \\
\hline & J_avg & $-0,293$ & 0,147 & $-1,990$ & $0,050 *$ \\
\hline & POU_avg & $-0,012$ & 0,158 & $-0,080$ & 0,938 \\
\hline \multirow[t]{2}{*}{$\begin{array}{l}\text { Kvaliteta komunikacije DOP-a } \\
\text { korištenjem društvenih mreža }\end{array}$} & $\begin{array}{l}\text { Facebook_ } \\
\text { da_ne }\end{array}$ & 0,264 & 0,173 & 1,530 & 0,130 \\
\hline & $\begin{array}{l}\text { Twitter_da_ } \\
\text { ne }\end{array}$ & 0,109 & 0,185 & 0,590 & 0,559 \\
\hline \multicolumn{6}{|c|}{ Kontrolne varijable } \\
\hline $\begin{array}{l}\text { Kategorija kupca } \\
\text { (B2B nasuprot B2C-u) }\end{array}$ & Kat_kupca & 0,050 & 0,198 & 0,250 & 0,803 \\
\hline Rast tržišta & Rast_tržišta & 0,387 & 0,156 & 2,480 & $0,015 * *$ \\
\hline Opseg tržišta & Opseg_tržišta & $-0,008$ & 0,184 & $-0,040$ & 0,967 \\
\hline Intenzitet konkurentnosti tržišta & Intenz_konk & 0,093 & 0,151 & 0,620 & 0,539 \\
\hline \multirow[t]{2}{*}{ Veličina poduzeća } & Br_zap & 0,000 & 0,000 & $-2,950$ & $0,004 * * *$ \\
\hline & Uk_prih & 0,000 & 0,000 & $-0,510$ & 0,608 \\
\hline Djelatnost & $\begin{array}{l}\text { Djelatnost_ } \\
\text { kod }\end{array}$ & 0,192 & 0,116 & 1,650 & 0,102 \\
\hline Privatno i javno vlasništvo & $\begin{array}{l}\text { Privatno_ } \\
\text { javno }\end{array}$ & $-0,022$ & 0,241 & $-0,090$ & 0,927 \\
\hline Domaće i strano vlasništvo & \begin{tabular}{|l} 
Domaće_ \\
strano
\end{tabular} & 0,244 & 0,182 & 1,340 & 0,183 \\
\hline \multicolumn{6}{|l|}{ Regresijska dijagnostika } \\
\hline Pseudo R Square & & & & & 0,344 \\
\hline
\end{tabular}

Izvor: autorski rad

Napomena: *** statistički značajno uz $1 \%$ vjerojatnosti, ** $5 \%$ vjerojatnosti, * $10 \%$ vjerojatnosti

Tablica 12. prikazuje procjenu kvantilne regresije; zavisna varijabla - dimenzija reputacije: vodstvo - $50 \%$ percentil. Modelom je protumačeno $34 \%$ odstupanja. Nezavisne varijable kojima se mjeri kvaliteta komunikacije DOP-a korištenjem mrežnih stranica i društvenih mreža, a koje imaju statistički značajan utjecaj na zavisnu varijablu (dimenzija 
reputacije: vodstvo) su: PRAV_avg (pozitivan utjecaj uz $1 \%$ vjerojatnosti), J_avg (negativan utjecaj uz $1 \%$ vjerojatnosti) i Facebook_da_ne (pozitivan utjecaj uz $1 \%$ vjerojatnosti). Kontrolne nezavisne varijable koje imaju statistički značajan utjecaj na zavisnu varijablu (dimenzija reputacije: vodstvo) su: rast tržišta (pozitivan utjecaj uz $1 \%$ ) i broj zaposlenih (negativan utjecaj uz $10 \%$ ).

Tablica 12. Procjena modela kvantilne regresije; zavisna varijabla - dimenzija reputacije: vodstvo - $50 \%$ percentil

\begin{tabular}{|c|c|c|c|c|c|}
\hline \multirow{2}{*}{ Grupa nezavisnih varijabli } & $\begin{array}{c}\text { Nezavisne } \\
\text { varijable }\end{array}$ & B & $\begin{array}{l}\text { Std. } \\
\text { Error }\end{array}$ & $\mathbf{t}$ & Sig. \\
\hline & _cons & 2,301 & 0,624 & 3,690 & $0,000 * * *$ \\
\hline \multirow{6}{*}{$\begin{array}{l}\text { Kvaliteta komunikacije DOP-a } \\
\text { korištenjem mrežnih stranica }\end{array}$} & R_avg & 0,058 & 0,133 & 0,430 & 0,666 \\
\hline & U_avg & 0,027 & 0,154 & 0,180 & 0,859 \\
\hline & T_avg & $-0,133$ & 0,150 & $-0,890$ & 0,375 \\
\hline & PRAV_avg & 0,488 & 0,149 & 3,280 & $0,002 * * *$ \\
\hline & J_avg & $-0,246$ & 0,125 & $-1,970$ & $0,053 *$ \\
\hline & POU_avg & $-0,169$ & 0,134 & $-1,260$ & 0,211 \\
\hline \multirow[t]{2}{*}{$\begin{array}{l}\text { Kvaliteta komunikacije DOP-a } \\
\text { korištenjem društvenih mreža }\end{array}$} & $\begin{array}{l}\text { Facebook_ } \\
\text { da_ne }\end{array}$ & 0,520 & 0,147 & 3,550 & $0,001 * * *$ \\
\hline & $\begin{array}{l}\text { Twitter_da_ } \\
\text { ne }\end{array}$ & 0,072 & 0,157 & 0,460 & 0,646 \\
\hline \multicolumn{6}{|c|}{ Kontrolne varijable } \\
\hline $\begin{array}{l}\text { Kategorija kupca } \\
\text { (B2B nasuprot B2C-u) }\end{array}$ & Kat_kupca & $-0,024$ & 0,168 & $-0,150$ & 0,885 \\
\hline Rast tržišta & Rast_tržišta & 0,408 & 0,132 & 3,080 & $0,003 * * *$ \\
\hline Opseg tržišta & Opseg_tržišta & 0,074 & 0,156 & 0,480 & 0,636 \\
\hline Intenzitet konkurentnosti tržišta & Intenz_konk & 0,100 & 0,128 & 0,780 & 0,436 \\
\hline \multirow[t]{2}{*}{ Veličina poduzeća } & Br_zap & 0,000 & 0,000 & $-1,940$ & $0,056^{*}$ \\
\hline & Uk_prih & 0,000 & 0,000 & $-1,590$ & 0,115 \\
\hline Djelatnost & $\begin{array}{l}\text { Djelatnost_ } \\
\text { kod }\end{array}$ & 0,109 & 0,099 & 1,110 & 0,270 \\
\hline Privatno i javno vlasništvo & $\begin{array}{l}\text { Privatno_ } \\
\text { javno }\end{array}$ & $-0,070$ & 0,204 & $-0,340$ & 0,732 \\
\hline Domaće i strano vlasništvo & $\begin{array}{l}\text { Domaće_ } \\
\text { strano }\end{array}$ & 0,083 & 0,154 & 0,540 & 0,592 \\
\hline \multicolumn{6}{|l|}{ Regresijska dijagnostika } \\
\hline Pseudo R Square & & & & & 0,340 \\
\hline
\end{tabular}

Izvor: autorski rad

Napomena: *** statistički značajno uz $1 \%$ vjerojatnosti, ** $5 \%$ vjerojatnosti, $* 10 \%$ vjerojatnosti

Tablica 13. prikazuje procjenu kvantilne regresije; zavisna varijabla - dimenzija reputacije: vodstvo - $75 \%$ percentil. Modelom je protumačeno 32,6 \% odstupanja. Može se zaključiti kako poduzeća koja objavljuju sadržaje vezane uz DOP na stranicama Facebooka, ujedno imaju i veću reputaciju s obzirom na vodstvo. 
I. Klopotan: Povezanost kvalitete online komuniciranja društveno odgovornog poslovanja i reputacije...

Tablica 13. Procjena modela kvantilne regresije; zavisna varijabla - dimenzija reputacije: vodstvo $-75 \%$ percentil

\begin{tabular}{|c|c|c|c|c|c|}
\hline \multirow[t]{2}{*}{ Grupa nezavisnih varijabli } & $\begin{array}{c}\text { Nezavisne } \\
\text { varijable }\end{array}$ & B & $\begin{array}{l}\text { Std. } \\
\text { Error }\end{array}$ & $\mathbf{t}$ & Sig. \\
\hline & _cons & 2,301 & $\mathbf{0 , 8 3 2}$ & 2,770 & $0,007 * * *$ \\
\hline \multirow{6}{*}{$\begin{array}{l}\text { Kvaliteta komunikacije DOP-a } \\
\text { korištenjem mrežnih stranica }\end{array}$} & R_avg & 0,098 & 0,178 & 0,550 & 0,582 \\
\hline & U_avg & 0,072 & 0,205 & 0,350 & 0,727 \\
\hline & T_avg & 0,063 & 0,199 & 0,320 & 0,751 \\
\hline & PRAV_avg & 0,192 & 0,198 & 0,970 & 0,337 \\
\hline & J_avg & $-0,087$ & 0,167 & $-0,520$ & 0,604 \\
\hline & POU_avg & $-0,348$ & 0,179 & $-1,950$ & 0,055 \\
\hline \multirow[t]{2}{*}{$\begin{array}{l}\text { Kvaliteta komunikacije DOP-a } \\
\text { korištenjem društvenih mreža }\end{array}$} & $\begin{array}{l}\text { Facebook_da_ } \\
\text { ne }\end{array}$ & 0,746 & 0,196 & 3,820 & $0,000 * * *$ \\
\hline & Twitter_da_ne & 0,051 & 0,210 & 0,240 & 0,810 \\
\hline \multicolumn{6}{|c|}{ Kontrolne varijable } \\
\hline $\begin{array}{l}\text { Kategorija kupca } \\
\text { (B2B nasuprot B2C-u) }\end{array}$ & Kat_kupca & 0,052 & 0,225 & 0,230 & 0,818 \\
\hline Rast tržišta & Rast_tržišta & 0,178 & 0,177 & 1,010 & 0,317 \\
\hline Opseg tržišta & Opseg_tržišta & 0,305 & 0,208 & 1,460 & 0,147 \\
\hline Intenzitet konkurentnosti tržišta & Intenz_konk & 0,140 & 0,171 & 0,820 & 0,414 \\
\hline \multirow[t]{2}{*}{ Veličina poduzeća } & Br_zap & 0,000 & 0,000 & $-1,440$ & 0,154 \\
\hline & Uk_prih & 0,000 & 0,000 & $-1,320$ & 0,189 \\
\hline Djelatnost & Djelatnost_kod & 0,164 & 0,131 & 1,250 & 0,216 \\
\hline Privatno i javno vlasništvo & Privatno_javno & $-0,100$ & 0,273 & $-0,370$ & 0,716 \\
\hline Domaće i strano vlasništvo & $\begin{array}{l}\text { Domaće } \\
\text { strano }\end{array}$ & $-0,048$ & 0,206 & $-0,230$ & 0,815 \\
\hline \multicolumn{6}{|l|}{ Regresijska dijagnostika } \\
\hline Pseudo R Square & & & & & 0,326 \\
\hline
\end{tabular}

Izvor: autorski rad

Napomena: $* * *$ statistički značajno uz $1 \%$ vjerojatnosti, ** $5 \%$ vjerojatnosti, $* 10 \%$ vjerojatnosti

Tablica 14. prikazuje procjenu kvantilne regresije; zavisna varijabla - dimenzija reputacije: vodstvo - $90 \%$ percentil. Modelom je protumačeno 38,9 \% odstupanja. Nezavisne varijable kojima se mjeri kvaliteta komunikacije DOP-a korištenjem mrežnih stranica i društvenih mreža, a koje imaju statistički značajan utjecaj na zavisnu varijablu (dimenzija reputacije: vodstvo) su: R_avg (pozitivan utjecaj uz $5 \%$ vjerojatnosti), T_avg (negativan utjecaj uz $1 \%$ vjerojatnosti), J_avg (negativan utjecaj uz $10 \%$ vjerojatnosti) i Facebook_ da_ne (pozitivan utjecaj uz $1 \%$ vjerojatnosti). Kontrolne nezavisne varijable koje imaju statistički značajan utjecaj na zavisnu varijablu (dimenzija reputacije: vodstvo) su: rast tržišta i djelatnost (pozitivan utjecaj uz $1 \%$ ), broj zaposlenih (negativan utjecaj uz $1 \%$ ), ukupan prihod (pozitivan utjecaj uz $5 \%$ ) i privatno i javno vlasništvo (negativan utjecaj uz $10 \%$, što ukazuje na to da poduzeća javnog vlasništva imaju manju reputacija). 
Tablica 14. Procjena modela kvantilne regresije; zavisna varijabla - dimenzija reputacije: vodstvo - $90 \%$ percentil

\begin{tabular}{|c|c|c|c|c|c|}
\hline \multirow[t]{2}{*}{ Grupa nezavisnih varijabli } & $\begin{array}{c}\text { Nezavisne } \\
\text { varijable }\end{array}$ & B & \begin{tabular}{|l|} 
Std. \\
Error
\end{tabular} & $\mathbf{t}$ & Sig. \\
\hline & _cons & 2,777 & 0,552 & 5,030 & $0,000 * * *$ \\
\hline \multirow{6}{*}{$\begin{array}{l}\text { Kvaliteta komunikacije DOP-a } \\
\text { korištenjem mrežnih stranica }\end{array}$} & R_avg & 0,301 & 0,118 & 2,540 & $0,013 * *$ \\
\hline & U_avg & 0,163 & 0,136 & 1,200 & 0,235 \\
\hline & T_avg & 0,373 & 0,132 & $-2,810$ & 0,006 *** \\
\hline & PRAV_avg & 0,141 & 0,132 & 1,070 & 0,286 \\
\hline & J_avg & $-0,214$ & 0,111 & $-1,940$ & $0,056^{*}$ \\
\hline & POU_avg & 0,013 & 0,119 & $-0,110$ & 0,911 \\
\hline \multirow[t]{2}{*}{$\begin{array}{l}\text { Kvaliteta komunikacije DOP-a } \\
\text { korištenjem društvenih mreža }\end{array}$} & $\begin{array}{l}\text { Facebook_ } \\
\text { da_ne }\end{array}$ & 0,347 & 0,130 & 2,670 & $0,009 * * *$ \\
\hline & Twitter_da_ne & 0,176 & 0,139 & 1,260 & 0,210 \\
\hline \multicolumn{6}{|c|}{ Kontrolne varijable } \\
\hline $\begin{array}{l}\text { Kategorija kupca } \\
\text { (B2B nasuprot B2C-u) }\end{array}$ & Kat_kupca & 0,045 & 0,149 & $-0,300$ & 0,763 \\
\hline Rast tržišta & Rast_tržišta & 0,326 & 0,117 & 2,780 & $0,007 * * *$ \\
\hline Opseg tržišta & Opseg_tržišta & 0,252 & 0,138 & 1,820 & 0,072 \\
\hline Intenzitet konkurentnosti tržišta & Intenz_konk & 0,120 & 0,113 & $-1,060$ & 0,292 \\
\hline \multirow[t]{2}{*}{ Veličina poduzeća } & Br_zap & 0,000 & 0,000 & $-4,730$ & $0,000 * * *$ \\
\hline & Uk_prih & 0,000 & 0,000 & 2,350 & $0,021 * *$ \\
\hline Djelatnost & $\begin{array}{l}\text { Djelatnost_ } \\
\text { kod }\end{array}$ & 0,313 & 0,087 & 3,580 & $0,001 * * *$ \\
\hline Privatno i javno vlasništvo & $\begin{array}{l}\text { Privatno } \\
\text { javno }\end{array}$ & 0,306 & 0,181 & $-1,690$ & $0,094 *$ \\
\hline Domaće i strano vlasništvo & $\begin{array}{l}\text { Domaće } \\
\text { strano }\end{array}$ & 0,217 & 0,137 & 1,590 & 0,116 \\
\hline \multicolumn{6}{|l|}{ Regresijska dijagnostika } \\
\hline Pseudo R Square & & & & & 0,389 \\
\hline
\end{tabular}

Izvor: autorski rad

Napomena: *** statistički značajno uz $1 \%$ vjerojatnosti, $* * 5 \%$ vjerojatnosti, * $10 \%$ vjerojatnosti

\section{Ispitivanje hipoteze $\mathrm{H3}$}

Tablica 15. prikazuje procjenu modela linearne regresije metodom najmanjih kvadrata; zavisna varijabla - dimenzija reputacije: radno okruženje. Modelom je protumačeno $26,5 \%$ odstupanja. Nezavisne varijable kojima se mjeri kvaliteta komunikacije DOP-a korištenjem mrežnih stranica i društvenih mreža, a koje imaju statistički značajan utjecaj na zavisnu varijablu (dimenzija reputacije: radno okruženje) su: PRAV_avg i Facebook_da_ne (pozitivan utjecaj uz $5 \%$ vjerojatnosti). Kontrolne nezavisne varijable koje imaju statistički značajan utjecaj na zavisnu varijablu (dimenzija reputacije: radno okruženje) su: rast tržišta (pozitivan utjecaj uz $5 \%$ ) i broj zaposlenih (negativan utjecaj uz $5 \%$ ). 
$\underline{\text { I. Klopotan: Povezanost kvalitete online komuniciranja društveno odgovornog poslovanja i reputacije... }}$

Tablica 15. Procjena modela linearne regresije metodom najmanjih kvadrata; zavisna varijabla - dimenzija reputacije: radno okruženje

\begin{tabular}{|c|c|c|c|c|c|c|}
\hline \multirow{2}{*}{$\begin{array}{c}\text { Grupa nezavisnih } \\
\text { varijabli }\end{array}$} & $\begin{array}{l}\text { Nezavisne } \\
\text { varijable }\end{array}$ & B & \begin{tabular}{c|} 
Std. \\
Error
\end{tabular} & $\mathbf{t}$ & Sig. & VIF \\
\hline & (Constant) & 2,952 & 0,493 & 5,988 & $0,000 * * *$ & \\
\hline \multirow{6}{*}{$\begin{array}{l}\text { Kvaliteta komunikacije } \\
\text { DOP-a korištenjem } \\
\text { mrežnih stranica }\end{array}$} & R_avg & $-0,060$ & 0,105 & $-0,566$ & 0,573 & 14,960 \\
\hline & U_avg & 0,053 & 0,121 & 0,432 & 0,667 & 14,897 \\
\hline & T_avg & $-0,134$ & 0,118 & $-1,133$ & 0,261 & 16,907 \\
\hline & PRAV_avg & 0,275 & 0,118 & 2,337 & $0,022 * *$ & 16,432 \\
\hline & J_avg & $-0,016$ & 0,099 & $-0,167$ & 0,868 & 12,862 \\
\hline & POU_avg & $-0,067$ & 0,106 & $-0,632$ & 0,529 & 11,630 \\
\hline \multirow{2}{*}{$\begin{array}{l}\text { Kvaliteta komunikacije } \\
\text { DOP-a korištenjem } \\
\text { društvenih mreža }\end{array}$} & $\begin{array}{l}\text { Facebook_ } \\
\text { da_ne }\end{array}$ & 0,252 & 0,116 & 2,175 & $0,033 * *$ & 1,492 \\
\hline & $\begin{array}{l}\text { Twitter_da } \\
\text { ne }\end{array}$ & 0,030 & 0,124 & 0,242 & 0,809 & 1,592 \\
\hline \multicolumn{7}{|c|}{ Kontrolne varijable } \\
\hline $\begin{array}{l}\text { Kategorija kupca (B2B } \\
\text { nasuprot B2C-u) }\end{array}$ & Kat_kupca & $-0,154$ & 0,133 & $-1,154$ & 0,252 & 1,968 \\
\hline Rast tržišta & Rast_tržišta & 0,231 & 0,105 & 2,207 & $0,030 * *$ & 1,766 \\
\hline Opseg tržišta & Opseg_tržišta & 0,071 & 0,123 & 0,577 & 0,566 & 2,570 \\
\hline $\begin{array}{l}\text { Intenzitet konkurentnosti } \\
\text { tržišta }\end{array}$ & Intenz_konk & $-0,086$ & 0,101 & $-0,849$ & 0,398 & 2,225 \\
\hline \multirow[t]{2}{*}{ Veličina poduzeća } & Br_zap & 0,000 & 0,000 & $-2,236$ & $0,028 * *$ & 1,781 \\
\hline & Uk_prih & 0,000 & 0,000 & $-0,296$ & 0,768 & 1,729 \\
\hline Djelatnost & $\begin{array}{l}\text { Djelatnost_ } \\
\text { kod }\end{array}$ & 0,093 & 0,078 & 1,200 & 0,234 & 1,764 \\
\hline $\begin{array}{l}\text { Privatno i javno } \\
\text { vlasništvo }\end{array}$ & $\begin{array}{l}\text { Privatno_ } \\
\text { javno }\end{array}$ & 0,258 & 0,161 & 1,598 & 0,114 & 2,050 \\
\hline $\begin{array}{l}\text { Domaće i strano } \\
\text { vlasništvo }\end{array}$ & $\begin{array}{l}\text { Domaće_ } \\
\text { strano }\end{array}$ & 0,169 & 0,122 & 1,384 & 0,170 & 1,621 \\
\hline \multicolumn{7}{|c|}{ Regresijska dijagnostika } \\
\hline R Square & & & & & & 0,391 \\
\hline Adjusted R Square & & & & & & 0,265 \\
\hline Durbin-Watson & & & & & & 1,171 \\
\hline
\end{tabular}

Izvor: autorski rad

Napomena: $* * *$ statistički značajno uz $1 \%$ vjerojatnosti, ** $5 \%$ vjerojatnosti, * $10 \%$ vjerojatnosti

Tablica 16. prikazuje procjenu kvantilne regresije; zavisna varijabla - dimenzija reputacije: radno okruženje. Modelom je protumačeno 27,9 \% odstupanja. Nezavisne varijable kojima se mjeri kvaliteta komunikacije DOP-a korištenjem mrežnih stranica i društvenih mreža, a koje imaju statistički značajan utjecaj na zavisnu varijablu (dimenzija reputacije: radno okruženje) su: PRAV_avg i Facebook_da_ne (pozitivan utjecaj uz $1 \%$ vjerojatnosti), U_avg (negativan utjecaj uz $1 \%$ vjerojatnosti), J_avg (negativan utjecaj uz $5 \%$ vjerojatno- 
sti) i POU_avg (pozitivan utjecaj uz $5 \%$ vjerojatnosti). Kontrolne nezavisne varijable koje imaju statistički značajan utjecaj na zavisnu varijablu (dimenzija reputacije: radno okruženje) su: intenzitet konkurentnosti tržišta i domaće-strano vlasništvo (pozitivan utjecaj uz 5 $\%$, što ukazuje da poduzeća u stranom vlasništvu imaju veću reputaciju s obzirom na radno okruženje), broj zaposlenih (negativan utjecaj uz 1 \%) i privatno i javno vlasništvo (pozitivan utjecaj uz $1 \%$, što ukazuje na to da poduzeća u javnom vlasništvu imaju veću reputaciju s obzirom na radno okruženje).

Tablica 16. Procjena modela kvantilne regresije; zavisna varijabla

- dimenzija reputacije: radno okruženje - $10 \%$ percentil

\begin{tabular}{|c|c|c|c|c|c|}
\hline \multirow[t]{2}{*}{ Grupa nezavisnih varijabli } & $\begin{array}{l}\text { Nezavisne } \\
\text { varijable }\end{array}$ & B & $\begin{array}{c}\text { Std. } \\
\text { Error }\end{array}$ & $\mathbf{t}$ & Sig. \\
\hline & _cons & 2,436 & 0,368 & 6,620 & $0,000 * * *$ \\
\hline \multirow{6}{*}{$\begin{array}{l}\text { Kvaliteta komunikacije DOP-a } \\
\text { korištenjem mrežnih stranica }\end{array}$} & R_avg & $-0,086$ & 0,079 & $-1,090$ & 0,279 \\
\hline & U_avg & $-0,304$ & 0,091 & $-3,350$ & $0,001 * * *$ \\
\hline & T_avg & 0,049 & 0,088 & 0,550 & 0,581 \\
\hline & PRAV_avg & 0,342 & 0,088 & 3,900 & $0,000 * * *$ \\
\hline & J_avg & $-0,174$ & 0,074 & $-2,360$ & $0,021 * *$ \\
\hline & POU_avg & 0,168 & 0,079 & 2,120 & $0,037 * *$ \\
\hline \multirow[t]{2}{*}{$\begin{array}{l}\text { Kvaliteta komunikacije DOP-a } \\
\text { korištenjem društvenih mreža }\end{array}$} & $\begin{array}{l}\text { Facebook } \\
\text { da ne }\end{array}$ & 0,292 & 0,086 & 3,380 & $0,001 * * *$ \\
\hline & Twitter_da_ne & $-0,043$ & 0,093 & $-0,470$ & 0,642 \\
\hline \multicolumn{6}{|c|}{ Kontrolne varijable } \\
\hline $\begin{array}{l}\text { Kategorija kupca } \\
\text { (B2B nasuprot B2C-u) }\end{array}$ & Kat kupca & $-0,088$ & 0,099 & $-0,890$ & 0,377 \\
\hline Rast tržišta & Rast_tržišta & 0,120 & 0,078 & 1,530 & 0,130 \\
\hline Opseg tržišta & Opseg_tržišta & 0,047 & 0,092 & 0,510 & 0,613 \\
\hline Intenzitet konkurentnosti tržišta & Intenz_konk & 0,179 & 0,076 & 2,370 & $0,020 * *$ \\
\hline \multirow{2}{*}{ Veličina poduzeća } & Br_zap & 0,000 & 0,000 & $-4,800$ & $0,000 * * *$ \\
\hline & Uk_prih & 0,000 & 0,000 & 1,210 & 0,228 \\
\hline Djelatnost & $\begin{array}{l}\text { Djelatnost_ } \\
\text { kod }\end{array}$ & 0,000 & 0,058 & 0,000 & 0,997 \\
\hline Privatno i javno vlasništvo & $\begin{array}{l}\text { Privatno_ } \\
\text { javno }\end{array}$ & 0,332 & 0,121 & 2,760 & $0,007 * * *$ \\
\hline Domaće i strano vlasništvo & $\begin{array}{l}\text { Domaće } \\
\text { strano }\end{array}$ & 0,193 & 0,091 & 2,130 & $0,036 * *$ \\
\hline \multicolumn{6}{|l|}{ Regresijska dijagnostika } \\
\hline Pseudo R Square & & & & & 0,279 \\
\hline
\end{tabular}

Izvor: autorski rad

Napomena: *** statistički značajno uz $1 \%$ vjerojatnosti, ** $5 \%$ vjerojatnosti, * $10 \%$ vjerojatnosti

Tablica 17. prikazuje procjenu kvantilne regresije; zavisna varijabla - dimenzija reputacije: radno okruženje - $25 \%$ percentil. Modelom je protumačeno 25,6 \% odstupanja. 
Nezavisna varijabla kojom se mjeri kvaliteta komunikacije DOP-a korištenjem mrežnih stranica, a koja ima statistički značajan utjecaj na zavisnu varijablu (dimenzija reputacije: radno okruženje) je PRAV_avg (pozitivan utjecaj uz 5 \% vjerojatnosti). Kontrolna nezavisna varijabla koja ima statistički značajan utjecaj na zavisnu varijablu (dimenzija reputacije: radno okruženje) je broj zaposlenih (negativan utjecaj uz $5 \%$ ).

Tablica 17. Procjena modela kvantilne regresije; zavisna varijabla

- dimenzija reputacije: radno okruženje - $25 \%$ percentil

\begin{tabular}{|c|c|c|c|c|c|}
\hline \multirow{2}{*}{ Grupa nezavisnih varijabli } & $\begin{array}{l}\text { Nezavisne } \\
\text { varijable }\end{array}$ & B & $\begin{array}{c}\text { Std. } \\
\text { Error }\end{array}$ & $\mathbf{t}$ & Sig. \\
\hline & _cons & 2,587 & 0,567 & 4,560 & $0,000 * * *$ \\
\hline \multirow{6}{*}{$\begin{array}{l}\text { Kvaliteta komunikacije DOP-a } \\
\text { korištenjem mrežnih stranica }\end{array}$} & R_avg & $-0,051$ & 0,121 & $-0,420$ & 0,677 \\
\hline & U_avg & 0,026 & 0,140 & 0,190 & 0,853 \\
\hline & \begin{tabular}{|l|} 
T_avg \\
\end{tabular} & $-0,152$ & 0,136 & $-1,120$ & 0,267 \\
\hline & PRAV_avg & 0,304 & 0,135 & 2,250 & $0,027 * *$ \\
\hline & J_avg & $-0,021$ & 0,114 & $-0,190$ & 0,852 \\
\hline & POU_avg & $-0,076$ & 0,122 & $-0,620$ & 0,535 \\
\hline \multirow[t]{2}{*}{$\begin{array}{l}\text { Kvaliteta komunikacije DOP-a } \\
\text { korištenjem društvenih mreža }\end{array}$} & $\begin{array}{l}\text { Facebook_ } \\
\text { da_ne }\end{array}$ & 0,188 & 0,133 & 1,410 & 0,162 \\
\hline & Twitter_da_ne & 0,040 & 0,143 & 0,280 & 0,779 \\
\hline \multicolumn{6}{|c|}{ Kontrolne varijable } \\
\hline $\begin{array}{l}\text { Kategorija kupca } \\
\text { (B2B nasuprot B2C-u) }\end{array}$ & Kat_kupca & $-0,026$ & 0,153 & $-0,170$ & 0,866 \\
\hline Rast tržišta & Rast_tržišta & 0,191 & 0,120 & 1,590 & 0,115 \\
\hline Opseg tržišta & Opseg_tržišta & 0,110 & 0,142 & 0,770 & 0,443 \\
\hline Intenzitet konkurentnosti tržišta & Intenz_konk & $-0,063$ & 0,116 & $-0,540$ & 0,587 \\
\hline \multirow[t]{2}{*}{ Veličina poduzeća } & Br_zap & 0,000 & 0,000 & $-2,360$ & $0,020 * *$ \\
\hline & Uk_prih & 0,000 & 0,000 & 0,080 & 0,940 \\
\hline Djelatnost & $\begin{array}{l}\text { Djelatnost__ } \\
\text { kod }\end{array}$ & 0,047 & 0,090 & 0,530 & 0,601 \\
\hline Privatno i javno vlasništvo & $\begin{array}{l}\text { Privatno_ } \\
\text { javno }\end{array}$ & 0,308 & 0,186 & 1,660 & 0,101 \\
\hline Domaće i strano vlasništvo & $\begin{array}{l}\begin{array}{l}\text { Domaće } \\
\text { strano }\end{array} \\
\end{array}$ & 0,168 & 0,140 & 1,200 & 0,233 \\
\hline \multicolumn{6}{|l|}{ Regresijska dijagnostika } \\
\hline Pseudo R Square & & & & & 0,256 \\
\hline
\end{tabular}

Izvor: autorski rad

Napomena: *** statistički značajno uz $1 \%$ vjerojatnosti, ** $5 \%$ vjerojatnosti, * 10 \% vjerojatnosti

Tablica 18. prikazuje procjenu kvantilne regresije; zavisna varijabla - dimenzija reputacije: radno okruženje - $50 \%$ percentil. Modelom je protumačeno $25,7 \%$ odstupanja. Nezavisne varijable kojima se mjeri kvaliteta komunikacije DOP-a korištenjem mrežnih stranica i društvenih mreža, a koje imaju statistički značajan utjecaj na zavisnu varijablu 
(dimenzija reputacije: radno okruženje) su: PRAV_avg (pozitivan utjecaj uz $10 \%$ vjerojatnosti) i Facebook_da_ne (pozitivan utjecaj uz $1 \%$ vjerojatnosti). Kontrolna nezavisna varijabla koja ima statistički značajan utjecaj na zavisnu varijablu (dimenzija reputacije: radno okruženje) je rast tržišta (pozitivan utjecaj uz $5 \%$ ).

Tablica 18. Procjena modela kvantilne regresije; zavisna varijabla - dimenzija reputacije: radno okruženje - $50 \%$ percentil

\begin{tabular}{|c|c|c|c|c|c|}
\hline \multirow[t]{2}{*}{ Grupa nezavisnih varijabli } & $\begin{array}{c}\text { Nezavisne } \\
\text { varijable }\end{array}$ & B & $\begin{array}{c}\text { Std. } \\
\text { Error }\end{array}$ & $\mathbf{t}$ & Sig. \\
\hline & _cons & 2,857 & 0,619 & 4,610 & $0,000 * * *$ \\
\hline \multirow{6}{*}{$\begin{array}{l}\text { Kvaliteta komunikacije DOP-a } \\
\text { korištenjem mrežnih stranica }\end{array}$} & R_avg & $-0,095$ & 0,132 & $-0,720$ & 0,475 \\
\hline & U_avg & 0,084 & 0,153 & 0,550 & 0,582 \\
\hline & T_avg & 0,090 & 0,149 & 0,610 & 0,545 \\
\hline & PRAV_avg & 0,254 & 0,148 & 1,720 & $0,089 *$ \\
\hline & J_avg & 0,014 & 0,124 & 0,110 & 0,913 \\
\hline & POU_avg & $-0,280$ & 0,133 & $-2,100$ & 0,038 \\
\hline \multirow[t]{2}{*}{$\begin{array}{l}\text { Kvaliteta komunikacije DOP-a } \\
\text { korištenjem društvenih mreža }\end{array}$} & $\begin{array}{l}\text { Facebook } \\
\text { da ne }\end{array}$ & 0,446 & 0,146 & 3,060 & $0,003 * * *$ \\
\hline & Twitter_da_ne & $-0,005$ & 0,156 & $-0,030$ & 0,972 \\
\hline \multicolumn{6}{|c|}{ Kontrolne varijable } \\
\hline $\begin{array}{l}\text { Kategorija kupca } \\
\text { (B2B nasuprot B2C-u) }\end{array}$ & Kat_kupca & $-0,226$ & 0,167 & $-1,350$ & 0,179 \\
\hline Rast tržišta & Rast_tržišta & 0,300 & 0,131 & 2,280 & $0,025^{* *}$ \\
\hline Opseg tržišta & Opseg_tržišta & 0,028 & 0,155 & 0,180 & 0,855 \\
\hline Intenzitet konkurentnosti tržišta & Intenz_konk & $-0,072$ & 0,127 & $-0,560$ & 0,575 \\
\hline \multirow{2}{*}{ Veličina poduzeća } & Br_zap & 0,000 & 0,000 & $-1,280$ & 0,205 \\
\hline & Uk_prih & 0,000 & 0,000 & $-0,900$ & 0,369 \\
\hline Djelatnost & $\begin{array}{l}\text { Djelatnost_ } \\
\text { kod }\end{array}$ & 0,087 & 0,098 & 0,890 & 0,377 \\
\hline Privatno i javno vlasništvo & $\begin{array}{l}\text { Privatno_ } \\
\text { javno }\end{array}$ & 0,277 & 0,203 & 1,370 & 0,176 \\
\hline Domaće i strano vlasništvo & $\begin{array}{l}\text { Domaće } \\
\text { strano }\end{array}$ & 0,102 & 0,153 & 0,670 & 0,506 \\
\hline \multicolumn{6}{|l|}{ Regresijska dijagnostika } \\
\hline Pseudo R Square & & & & & 0,257 \\
\hline
\end{tabular}

Izvor: autorski rad

Napomena: *** statistički značajno uz $1 \%$ vjerojatnosti, ** $5 \%$ vjerojatnosti, * $10 \%$ vjerojatnosti

Tablica 19. prikazuje procjenu kvantilne regresije; zavisna varijabla - dimenzija reputacije: radno okruženje - $75 \%$ percentil. Modelom je protumačeno 29,8 \% odstupanja. Nezavisne varijable kojima se mjeri kvaliteta komunikacije DOP-a korištenjem mrežnih stranica i društvenih mreža, a koje imaju statistički značajan utjecaj na zavisnu varijablu (dimenzija reputacije: radno okruženje) su: PRAV_avg (pozitivan utjecaj uz $5 \%$ vjerojat- 
nosti) i Facebook_da_ne (pozitivan utjecaj uz $1 \%$ vjerojatnosti). Kontrolne nezavisne varijable nemaju statistički značajan utjecaj na zavisnu varijablu (dimenzija reputacije: radno okruženje).

Tablica 19. Procjena modela kvantilne regresije; zavisna varijabla - dimenzija reputacije: radno okruženje - $75 \%$ percentil

\begin{tabular}{|c|c|c|c|c|c|}
\hline \multirow{2}{*}{ Grupa nezavisnih varijabli } & $\begin{array}{l}\text { Nezavisne } \\
\text { varijable }\end{array}$ & B & $\begin{array}{l}\text { Std. } \\
\text { Error }\end{array}$ & $\mathbf{t}$ & Sig. \\
\hline & cons & 3,268 & 0,718 & 4,550 & $0,000 * * *$ \\
\hline \multirow{6}{*}{$\begin{array}{l}\text { Kvaliteta komunikacije DOP-a } \\
\text { korištenjem mrežnih stranica }\end{array}$} & R_avg & $-0,048$ & 0,154 & $-0,320$ & 0,753 \\
\hline & U_avg & 0,100 & 0,177 & 0,560 & 0,574 \\
\hline & T_avg & 0,033 & 0,172 & 0,190 & 0,847 \\
\hline & PRAV_avg & 0,297 & 0,171 & 1,730 & $0,087 * *$ \\
\hline & J_avg & $-0,060$ & 0,144 & $-0,410$ & 0,680 \\
\hline & POU_avg & $-0,241$ & 0,154 & $-1,560$ & 0,122 \\
\hline \multirow[t]{2}{*}{$\begin{array}{l}\text { Kvaliteta komunikacije DOP-a } \\
\text { korištenjem društvenih mreža }\end{array}$} & $\begin{array}{l}\text { Facebook_ } \\
\text { da_ne }\end{array}$ & 0,469 & 0,169 & 2,780 & $0,007 * * *$ \\
\hline & Twitter_da_ne & $-0,064$ & 0,181 & $-0,350$ & 0,725 \\
\hline \multicolumn{6}{|c|}{ Kontrolne varijable } \\
\hline $\begin{array}{l}\text { Kategorija kupca (B2B nasuprot } \\
\text { B2C-u) }\end{array}$ & Kat_kupca & $-0,298$ & 0,194 & $-1,540$ & 0,128 \\
\hline Rast tržišta & Rast_tržišta & 0,005 & 0,152 & 0,030 & 0,973 \\
\hline Opseg tržišta & Opseg_tržišta & 0,234 & 0,180 & 1,300 & 0,197 \\
\hline Intenzitet konkurentnosti tržišta & Intenz_konk & $-0,096$ & 0,147 & $-0,650$ & 0,516 \\
\hline \multirow[t]{2}{*}{ Veličina poduzeća } & Br_zap & 0,000 & 0,000 & $-0,070$ & 0,941 \\
\hline & Uk_prih & 0,000 & 0,000 & $-1,100$ & 0,273 \\
\hline Djelatnost & $\begin{array}{l}\text { Djelatnost_ } \\
\text { kod }\end{array}$ & 0,184 & 0,113 & 1,620 & 0,109 \\
\hline Privatno i javno vlasništvo & $\begin{array}{l}\begin{array}{l}\text { Privatno_ } \\
\text { javno }\end{array} \\
\end{array}$ & 0,238 & 0,235 & 1,010 & 0,315 \\
\hline Domaće i strano vlasništvo & $\begin{array}{l}\text { Domacće_ } \\
\text { strano }\end{array}$ & 0,050 & 0,177 & 0,280 & 0,780 \\
\hline \multicolumn{6}{|l|}{ Regresijska dijagnostika } \\
\hline Pseudo R Square & & & & & 0,298 \\
\hline
\end{tabular}

Izvor: autorski rad

Napomena: $* * *$ statistički značajno uz $1 \%$ vjerojatnosti, ** $5 \%$ vjerojatnosti, $* 10 \%$ vjerojatnosti

Tablica 20. prikazuje procjenu kvantilne regresije; zavisna varijabla - dimenzija reputacije: radno okruženje - $90 \%$ percentil. Modelom je protumačeno 38,8 \% odstupanja. Nezavisne varijable kojima se mjeri kvaliteta komunikacije DOP-a korištenjem mrežnih stranica, a koje imaju statistički značajan utjecaj na zavisnu varijablu (dimenzija reputacije: radno okruženje) su: R_avg i U_avg (pozitivan utjecaj uz 5 \% vjerojatnosti), J_avg i POU_avg (negativan utjecaj uz $1 \%$ vjerojatnosti) i PRAV_avg (pozitivan utjecaj uz $1 \%$ vje- 
rojatnosti). Kontrolne nezavisne varijable koje imaju statistički značajan utjecaj na zavisnu varijablu (dimenzija reputacije: radno okruženje) su: rast tržišta i domaće-strano vlasništvo (pozitivan utjecaj uz $5 \%$, što ukazuje da poduzeća u stranom vlasništvu imaju veću reputaciju s obzirom na radno okruženje), broj zaposlenih (negativan utjecaj uz $10 \%$ ), ukupan prihod (negativan utjecaj uz $5 \%$ ), djelatnost (pozitivan utjecaj uz $1 \%$, što ukazuje da poduzeća koja se pretežito bave uslugama imaju veću reputaciju s obzirom na radno okruženje) i privatno i javno vlasništvo (pozitivan utjecaj uz $10 \%$, poduzeća u javnom vlasništvu imaju veću reputaciju s obzirom na radno okruženje).

Tablica 20. Procjena modela kvantilne regresije; zavisna varijabla

- dimenzija reputacije: radno okruženje - $90 \%$ percentil

\begin{tabular}{|c|c|c|c|c|c|}
\hline \multirow{2}{*}{ Grupa nezavisnih varijabli } & $\begin{array}{l}\text { Nezavisne } \\
\text { varijable }\end{array}$ & B & \begin{tabular}{l|} 
Std. \\
Error
\end{tabular} & $\mathbf{t}$ & Sig. \\
\hline & _cons & 2,584 & 0,471 & 5,490 & $0,000 * * *$ \\
\hline \multirow{6}{*}{$\begin{array}{l}\text { Kvaliteta komunikacije DOP-a } \\
\text { korištenjem mrežnih stranica }\end{array}$} & R_avg & 0,240 & 0,101 & 2,380 & $0,020 * *$ \\
\hline & U_avg & 0,240 & 0,116 & 2,070 & $0,042 * *$ \\
\hline & T_avg & $-0,125$ & 0,113 & $-1,110$ & 0,270 \\
\hline & PRAV_avg & 0,315 & 0,112 & 2,810 & $0,006 * * *$ \\
\hline & J_avg & $-0,263$ & 0,094 & $-2,790$ & $0,007 * * *$ \\
\hline & POU_avg & $-0,287$ & 0,101 & $-2,840$ & $0,006 * * *$ \\
\hline \multirow[t]{2}{*}{$\begin{array}{l}\text { Kvaliteta komunikacije DOP-a } \\
\text { korištenjem društvenih mreža }\end{array}$} & $\begin{array}{l}\text { Facebook_ } \\
\text { da_ne }\end{array}$ & 0,076 & 0,111 & 0,680 & 0,496 \\
\hline & $\begin{array}{l}\text { Twitter_da_ } \\
\text { ne }\end{array}$ & 0,012 & 0,119 & 0,100 & 0,920 \\
\hline \multicolumn{6}{|c|}{ Kontrolne varijable } \\
\hline $\begin{array}{l}\text { Kategorija kupca (B2B nasuprot } \\
\text { B2C-u) }\end{array}$ & Kat_kupca & $-0,128$ & 0,127 & $-1,000$ & 0,318 \\
\hline Rast tržišta & Rast_tržišta & 0,228 & 0,100 & 2,280 & $0,025 * *$ \\
\hline Opseg tržišta & Opseg_tržišta & 0,169 & 0,118 & 1,430 & 0,155 \\
\hline Intenzitet konkurentnosti tržišta & Intenz_konk & $-0,056$ & 0,097 & $-0,580$ & 0,566 \\
\hline \multirow{2}{*}{ Veličina poduzeća } & Br_zap & 0,000 & 0,000 & $-1,700$ & $0,093 *$ \\
\hline & Uk_prih & 0,000 & 0,000 & $-2,190$ & $0,031 * *$ \\
\hline Djelatnost & $\begin{array}{l}\text { Djelatnost_ } \\
\text { kod }\end{array}$ & 0,246 & 0,074 & 3,300 & $0,001 * * *$ \\
\hline Privatno i javno vlasništvo & $\begin{array}{l}\text { Privatno_ } \\
\text { javno }\end{array}$ & 0,302 & 0,154 & 1,960 & $0,054^{*}$ \\
\hline Domaće i strano vlasništvo & $\begin{array}{l}\text { Domaće_ } \\
\text { strano }\end{array}$ & 0,288 & 0,116 & 2,470 & $0,015 * *$ \\
\hline \multicolumn{6}{|l|}{ Regresijska dijagnostika } \\
\hline Pseudo R Square & & & & & 0,368 \\
\hline
\end{tabular}

Izvor: autorski rad

Napomena: *** statistički značajno uz $1 \%$ vjerojatnosti, ** $5 \%$ vjerojatnosti, * $10 \%$ vjerojatnosti 


\section{Diskusija rezultata}

Tablica 21. prikazuje statističku značajnost modela linearne i kvantilne regresije za dimenziju reputacije: proizvodi i usluge. U svim prikazanim modelima barem jedna od nezavisnih varijabli kojima se mjeri kvaliteta komunikacije DOP-a korištenjem mrežnih stranica ima statistički značajan utjecaj na zavisnu varijablu dimenzija reputacije: proizvodi i usluge. Varijabla PRAV_avg ima pozitivan utjecaj u modelima (modeli LSQ, P10 \% i P25 \%), kao i varijabla POU_avg (model P10 \%). Zanimljiv je rezultat da varijable U_avg, T_avg i J_avg imaju negativan utjecaj na reputaciju poduzeća, koja imaju najnižu reputaciju s obzirom na proizvode i usluge (pripadaju u $10 \%$ poduzeća koja su najslabije ocijenjena s obzirom na taj kriterij). Može se pretpostaviti da poduzeća koja već imaju nisku reputaciju s obzirom na proizvode i usluge istu ne mogu popraviti objavama aktivnosti DOP-a na mrežnim stranicama jer se iste tumače kao „iritantan“ pokušaj poduzeća da poboljša svoju lošu reputaciju. Također, u svim modelima (osim modelu kvantilne regresije P10 \%), varijabla kojom se mjeri kvaliteta komunikacije DOP-a korištenjem društvenih mreža ima statistički značajan utjecaj na zavisnu varijablu dimenzija reputacije: proizvodi $i$ usluge.

Kontrolne nezavisne varijable vezane uz karakteristike tržišta koje imaju statistički značajan utjecaj na zavisnu varijablu (dimenzija reputacije: proizvodi i usluge) su: rast tržišta (pozitivan utjecaj u modelima LSQ, P10 \%, P75 \% i P90 \%), opseg tržišta (pozitivan utjecaj u modelima P50 \% i P75 \%), kao i intenzitet konkurentnosti (pozitivan utjecaj u modelima P10 \% i P25 \%). Kontrolne nezavisne varijable vezane uz karakteristike poduzeća koje imaju statistički značajan utjecaj na zavisnu varijablu (dimenzija reputacije: proizvodi i usluge) su: broj zaposlenih (negativan utjecaj u modelima LSQ, P10 \% i P25 \%), ukupan prihod (negativna utjecaj u modelu P10 \%) i djelatnost (pozitivan utjecaj uslužnih djelatnosti u modelu P90 \%). Na temelju prikazanih rezultata može se zaključiti kako se prihvaća prva hipoteza $\mathrm{H} 1$ o utjecaju nezavisnih varijabli kojima se mjeri kvaliteta komunikacije DOP-a korištenjem mrežnih stranica, društvenih mreža, karakteristika tržišta i poduzeća na zavisnu varijablu dimenzija reputacije: proizvodi i usluge.

Tablica 21. Statističke značajnosti modela linearne i kvantilne regresije - dimenzija reputacije: proizvodi i usluge

\begin{tabular}{|c|c|c|c|c|c|c|c|}
\hline \multirow{2}{*}{$\begin{array}{c}\text { Grupa nezavisnih } \\
\text { varijabli }\end{array}$} & $\begin{array}{c}\text { Nezavisne } \\
\text { varijable }\end{array}$ & LSQ & $10 \%$ & $25 \%$ & $50 \%$ & $75 \%$ & $90 \%$ \\
\hline & Konstanta & $+1 \%$ & $+1 \%$ & $+1 \%$ & $+1 \%$ & $+1 \%$ & $+1 \%$ \\
\hline \multirow{6}{*}{$\begin{array}{l}\text { Kvaliteta } \\
\text { komunikacije DOP-a } \\
\text { korištenjem mrežnih } \\
\text { stranica (H1a) }\end{array}$} & R_avg & $\varnothing$ & $\varnothing$ & $\varnothing$ & $\varnothing$ & $\varnothing$ & $\varnothing$ \\
\hline & U_avg & $\varnothing$ & $-1 \%$ & $\varnothing$ & $\varnothing$ & $\varnothing$ & $\varnothing$ \\
\hline & T_avg & $\varnothing$ & $-1 \%$ & $\varnothing$ & $\varnothing$ & $\varnothing$ & $\varnothing$ \\
\hline & PRAV_avg & $+10 \%$ & $+1 \%$ & $+10 \%$ & $\varnothing$ & $\varnothing$ & $\varnothing$ \\
\hline & J_avg & $\varnothing$ & $-1 \%$ & $\varnothing$ & $\varnothing$ & $\varnothing$ & $\varnothing$ \\
\hline & POU_avg & $\varnothing$ & $+1 \%$ & $\varnothing$ & $\varnothing$ & $\varnothing$ & $\varnothing$ \\
\hline \multirow{2}{*}{\begin{tabular}{|l|} 
Kvaliteta \\
komunikacije \\
DOP-a korištenjem \\
društvenih mreža \\
(H1a) \\
\end{tabular}} & $\begin{array}{l}\text { Facebook_ } \\
\text { da_ne }\end{array}$ & $+5 \%$ & $\varnothing$ & $+5 \%$ & $+1 \%$ & $+1 \%$ & $+1 \%$ \\
\hline & $\begin{array}{l}\text { Twitter_da_ } \\
\text { ne }\end{array}$ & $\varnothing$ & $\varnothing$ & $\varnothing$ & $\varnothing$ & $\varnothing$ & $\varnothing$ \\
\hline
\end{tabular}




\begin{tabular}{|c|c|c|c|c|c|c|c|}
\hline \multirow{2}{*}{$\begin{array}{c}\text { Grupa nezavisnih } \\
\text { varijabli }\end{array}$} & $\begin{array}{l}\text { Nezavisne } \\
\text { varijable }\end{array}$ & LSQ & $10 \%$ & $25 \%$ & $50 \%$ & $75 \%$ & $90 \%$ \\
\hline & Konstanta & $+1 \%$ & $+1 \%$ & $+1 \%$ & $+1 \%$ & $+1 \%$ & $+1 \%$ \\
\hline \multicolumn{8}{|c|}{ Kontrolne varijable } \\
\hline $\begin{array}{l}\text { Kategorija kupca } \\
\text { (B2B nasuprot } \\
\text { B2C-u) }\end{array}$ & Kat_kupca & $\varnothing$ & $\varnothing$ & $\varnothing$ & $\varnothing$ & $\varnothing$ & $\varnothing$ \\
\hline Rast tržišta & Rast_tržišta & $+5 \%$ & $+1 \%$ & $\varnothing$ & $\varnothing$ & $+10 \%$ & $+1 \%$ \\
\hline Opseg tržišta & Opseg_tržišta & $\varnothing$ & $\varnothing$ & $+10 \%$ & $+10 \%$ & $+5 \%$ & $\varnothing$ \\
\hline $\begin{array}{l}\text { Intenzitet } \\
\text { konkurentnosti tržišta }\end{array}$ & Intenz konk & $\varnothing$ & $+1 \%$ & $+5 \%$ & $\varnothing$ & $\varnothing$ & $\varnothing$ \\
\hline \multirow[t]{2}{*}{ Veličina poduzeća } & Br_zap & $-5 \%$ & $-1 \%$ & $-5 \%$ & $\varnothing$ & $\varnothing$ & $\varnothing$ \\
\hline & Uk_prih & $\varnothing$ & $-5 \%$ & $\varnothing$ & $\varnothing$ & $\varnothing$ & $\varnothing$ \\
\hline Djelatnost & $\begin{array}{l}\text { Djelatnost_ } \\
\text { kod }\end{array}$ & $\varnothing$ & $\varnothing$ & $\varnothing$ & $\varnothing$ & $\varnothing$ & $+5 \%$ \\
\hline $\begin{array}{l}\text { Privatno i javno } \\
\text { vlasništvo }\end{array}$ & $\begin{array}{l}\begin{array}{l}\text { Privatno_ } \\
\text { javno }\end{array} \\
\end{array}$ & $\varnothing$ & $\varnothing$ & $\varnothing$ & $\varnothing$ & $\varnothing$ & $\varnothing$ \\
\hline $\begin{array}{l}\text { Domaće i strano } \\
\text { vlasništvo }\end{array}$ & $\begin{array}{l}\text { Domaće } \\
\text { strano }\end{array}$ & $\varnothing$ & $\varnothing$ & $\varnothing$ & $\varnothing$ & $\varnothing$ & $\varnothing$ \\
\hline \multirow{3}{*}{$\begin{array}{l}\text { Regresijska } \\
\text { dijagnostika }\end{array}$} & R Square & 0,509 & 0,377 & 0,276 & 0,255 & 0,333 & 0,388 \\
\hline & $\begin{array}{l}\text { Adjusted R } \\
\text { Square }\end{array}$ & 0,368 & - & - & - & - & - \\
\hline & $\begin{array}{l}\text { Durbin- } \\
\text { Watson }\end{array}$ & 1,009 & & & & & \\
\hline
\end{tabular}

Izvor: autorski rad

Napomena: $\varnothing$ - parametar nije statistički značajan, $+1 \%$ - pozitivna povezanost uz značajnost od $1 \%,+5 \%$ - pozitivna povezanost uz značajnost od $5 \%$; +10 \% - pozitivna povezanost uz značajnost od $10 \%,-1 \%$ - negativna povezanost uz značajnost od $1 \%,-5 \%$ - negativna povezanost uz značajnost od $5 \%$; -10 \% - negativna povezanost uz značajnost od $10 \%$

Tablica 22. prikazuje statističku značajnost modela linearne i kvantilne regresije za dimenziju reputacije: vodstvo. U svim prikazanim modelima barem jedna od nezavisnih varijabli kojima se mjeri kvaliteta komunikacije DOP-a korištenjem mrežnih stranica ima statistički značajan utjecaj na zavisnu varijablu dimenzija reputacije: proizvodi i usluge. Varijabla PRAV_avg ima pozitivan utjecaj u modelima (modeli LSQ, P10 \%, P25 \%, P50 \%), kao i varijabla POU_avg (model P10 \%). Zanimljiv je rezultat da varijable U_avg i J_avg imaju negativan utjecaj na reputaciju poduzeća (U_avg samo za $10 \%$ najslabije ocijenjenih poduzeća, a J_avg za modele P10 \%,P25 \%, P50 \% i P.90 \%). Može se zaključiti kako se jasnoća komuniciranja DOP-a putem mrežnih stranica poduzeća negativno odražava na reputaciju vodstva gotovo svih skupina poduzeća. Također, u svim modelima (osim modelu kvantilne regresije P25 \%) varijabla kojom se mjeri kvaliteta komunikacije DOP-a korištenjem društvenih mreža ima statistički značajan utjecaj na zavisnu varijablu dimenzija reputacije: vodstvo.

Kontrolne nezavisne varijable vezane uz karakteristike tržišta koje imaju statistički značajan utjecaj na zavisnu varijablu (dimenzija reputacije: vodstvo) su: rast tržišta (poziti- 
van utjecaj u modelima LSQ, P10 \%, P25 \%, P50 \% i P90 \%), kao i intenzitet konkurentnosti (pozitivan utjecaj u modelu P25 \%). Kontrolne nezavisne varijable vezane uz karakteristike poduzeća koje imaju statistički značajan utjecaj na zavisnu varijablu (dimenzija reputacije: proizvodi i usluge) su: broj zaposlenih (negativan utjecaj u modelima LSQ, P10 \%, P25 \%, P50 \% i P90 \%), ukupan prihod (pozitivan utjecaj u modelu P90 \%), djelatnost (pozitivan utjecaj uslužnih djelatnosti u modelu P90 \%) i privatno i javno vlasništvo (negativan utjecaj u modelu P90 \%, što ukazuje na nižu reputaciju poduzeća u javnom vlasništvu).

Na temelju prikazanih rezultata može se zaključiti kako se prihvaća druga hipoteza $\mathrm{H} 2$ ovoga rada o utjecaju nezavisnih varijabli kojima se mjeri kvaliteta komunikacije DOP-a korištenjem mrežnih stranica, društvenih mreža, karakteristika tržišta i poduzeća na zavisnu varijablu dimenzija reputacije: vodstvo.

Tablica 22. Statističke značajnosti modela linearne i kvantilne regresije - dimenzija reputacije: vodstvo

\begin{tabular}{|c|c|c|c|c|c|c|c|}
\hline \multirow{2}{*}{$\begin{array}{c}\text { Grupa nezavisnih } \\
\text { varijabli }\end{array}$} & $\begin{array}{l}\text { Nezavisne } \\
\text { varijable }\end{array}$ & LSQ & $10 \%$ & $25 \%$ & $50 \%$ & $75 \%$ & $90 \%$ \\
\hline & Konstanta & $+1 \%$ & $+1 \%$ & $+1 \%$ & $+1 \%$ & $+1 \%$ & $+1 \%$ \\
\hline \multirow{6}{*}{$\begin{array}{l}\text { Kvaliteta komunikacije } \\
\text { DOP-a korištenjem } \\
\text { mrežnih stranica (H1a) }\end{array}$} & R_avg & $\varnothing$ & $\varnothing$ & $\varnothing$ & $\varnothing$ & $\varnothing$ & $+5 \%$ \\
\hline & U_avg & $\varnothing$ & $-1 \%$ & $\varnothing$ & $\varnothing$ & $\varnothing$ & $\varnothing$ \\
\hline & T_avg & $\varnothing$ & $\varnothing$ & $\varnothing$ & $\varnothing$ & $\varnothing$ & $+1 \%$ \\
\hline & \begin{tabular}{|l|} 
PRAV_avg \\
\end{tabular} & $+5 \%$ & $+5 \%$ & $+1 \%$ & $+1 \%$ & $\varnothing$ & $\varnothing$ \\
\hline & \begin{tabular}{|l} 
J_avg \\
\end{tabular} & $\varnothing$ & $-10 \%$ & $-10 \%$ & $-10 \%$ & $\varnothing$ & $-10 \%$ \\
\hline & POU_avg & $\varnothing$ & $+1 \%$ & $\varnothing$ & $\varnothing$ & $\varnothing$ & $\varnothing$ \\
\hline \multirow{2}{*}{$\begin{array}{l}\text { Kvaliteta komunikacije } \\
\text { DOP-a korištenjem } \\
\text { društvenih mreža (H1a) }\end{array}$} & $\begin{array}{l}\text { Facebook_ } \\
\text { da_ne }\end{array}$ & $+5 \%$ & $+5 \%$ & $\varnothing$ & $+1 \%$ & $+1 \%$ & $+1 \%$ \\
\hline & $\begin{array}{l}\text { Twitter_da_ } \\
\text { ne }\end{array}$ & $\varnothing$ & $\varnothing$ & $\varnothing$ & $\varnothing$ & $\varnothing$ & $\varnothing$ \\
\hline \multicolumn{8}{|c|}{ Kontrolne varijable } \\
\hline $\begin{array}{l}\text { Kategorija kupca (B2B } \\
\text { nasuprot B2C-u) }\end{array}$ & Kat_kupca & $\varnothing$ & $\varnothing$ & $\varnothing$ & $\varnothing$ & $\varnothing$ & $\varnothing$ \\
\hline Rast tržišta & $\begin{array}{l}\text { Rast_- } \\
\text { tržišta }\end{array}$ & $+1 \%$ & $+10 \%$ & $+5 \%$ & $+1 \%$ & $\varnothing$ & $+1 \%$ \\
\hline Opseg tržišta & $\begin{array}{l}\text { Opseg_ } \\
\text { tržišta }\end{array}$ & $\varnothing$ & $\varnothing$ & $\varnothing$ & $\varnothing$ & $\varnothing$ & $\varnothing$ \\
\hline $\begin{array}{l}\text { Intenzitet konkurentnosti } \\
\text { tržišta }\end{array}$ & $\begin{array}{l}\text { Intenz_ } \\
\text { konk }\end{array}$ & $\varnothing$ & $+5 \%$ & $\varnothing$ & $\varnothing$ & $\varnothing$ & $\varnothing$ \\
\hline \multirow[t]{2}{*}{ Veličina poduzeća } & Br_zap & $-5 \%$ & $-1 \%$ & $-1 \%$ & $-10 \%$ & $\varnothing$ & $-1 \%$ \\
\hline & Uk_prih & $\varnothing$ & $\varnothing$ & $\varnothing$ & $\varnothing$ & $\varnothing$ & $+5 \%$ \\
\hline Djelatnost & $\begin{array}{l}\text { Djelatnost__ } \\
\text { kod }\end{array}$ & $\varnothing$ & $\varnothing$ & $\varnothing$ & $\varnothing$ & $\varnothing$ & $+1 \%$ \\
\hline $\begin{array}{l}\text { Privatno i javno } \\
\text { vlasništvo }\end{array}$ & \begin{tabular}{|l} 
Privatno_ \\
javno
\end{tabular} & $\varnothing$ & $\varnothing$ & $\varnothing$ & $\varnothing$ & $\varnothing$ & $-10 \%$ \\
\hline $\begin{array}{l}\text { Domaće i strano } \\
\text { vlasništvo }\end{array}$ & \begin{tabular}{|l}
$\begin{array}{l}\text { Domaće_ } \\
\text { strano }\end{array}$ \\
\end{tabular} & $\varnothing$ & $\varnothing$ & $\varnothing$ & $\varnothing$ & $\varnothing$ & $\varnothing$ \\
\hline
\end{tabular}




\begin{tabular}{|c|c|c|c|c|c|c|c|}
\hline \multirow{2}{*}{$\begin{array}{c}\text { Grupa nezavisnih } \\
\text { varijabli }\end{array}$} & $\begin{array}{l}\text { Nezavisne } \\
\text { varijable }\end{array}$ & LSQ & $10 \%$ & $25 \%$ & $50 \%$ & $75 \%$ & $90 \%$ \\
\hline & Konstanta & $+1 \%$ & $+1 \%$ & $+1 \%$ & $+1 \%$ & $+1 \%$ & $+1 \%$ \\
\hline \multirow[t]{3}{*}{ Regresijska dijagnostika } & $R$ Square & 0,472 & 0,394 & 0,344 & 0,340 & 0,326 & 0,389 \\
\hline & $\begin{array}{l}\text { Adjusted } R \\
\text { Square }\end{array}$ & 0,362 & - & - & - & - & - \\
\hline & $\begin{array}{l}\text { Durbin- } \\
\text { Watson }\end{array}$ & 1,081 & - & - & - & - & - \\
\hline
\end{tabular}

Napomena: $\varnothing$ - parametar nije statistički značajan, $+1 \%$ - pozitivna povezanost uz značajnost od $1 \%,+5 \%$ - pozitivna povezanost uz značajnost od $5 \% ;+10 \%$ - pozitivna povezanost uz značajnost od $10 \%,-1 \%$ - negativna povezanost uz značajnost od $1 \%,-5 \%$ - negativna povezanost uz značajnost od $5 \%$; -10 \% - negativna povezanost uz značajnost od $10 \%$

Tablica 23. prikazuje statističku značajnost modela linearne i kvantilne regresije za dimenziju reputacije: radni odnosi. U svim prikazanim modelima barem jedna od nezavisnih varijabli kojima se mjeri kvaliteta komunikacije DOP-a korištenjem mrežnih stranica ima statistički značajan utjecaj na zavisnu varijablu dimenzija reputacije: radni odnosi. Varijabla PRAV_avg ima pozitivan utjecaj u svim modelima (modeli LSQ, P10 \%, P25 \%, P50 \%, P75 \% i P90 \%), kao i varijabla POU_avg (model P10 \%). Zanimljiv je rezultat da varijable U_avg i J_avg imaju negativan utjecaj na reputaciju poduzeća koja imaju najnižu reputaciju, ali i najvišu reputaciju s obzirom na radne odnose (pripadaju u $10 \%$ poduzeća koja su najslabije ocijenjena s obzirom na taj kriterij i $90 \%$ poduzeća koja su najbolje ocijenjena s obzirom na taj kriterij). Kao i prethodno, može se pretpostaviti da poduzeća koja već imaju nisku reputaciju s obzirom na vodstvo, istu ne mogu popraviti objavama aktivnosti DOP-a na mrežnim stranicama jer se iste tumače kao „iritantan“ pokušaj poduzeća da poboljša svoju lošu reputaciju. Međutim, poduzeća koja su također najbolje ocijenjena s obzirom na reputaciju nemaju koristi od jasnoće, redovitosti i pouzdanosti objava DOP-a. Ovaj rezultat trebao bi se dodatno istražiti. Također, u svim modelima (osim modelu kvantilne regresije P25 \% i P75 \%) varijabla kojom se mjeri kvaliteta komunikacije DOP-a korištenjem društvenih mreža ima statistički značajan utjecaj na zavisnu varijablu dimenzija reputacije: radni odnosi.

Kontrolne nezavisne varijable vezane uz karakteristike tržišta koje imaju statistički značajan utjecaj na zavisnu varijablu (dimenzija reputacije: radni odnosi) su: rast tržišta (pozitivan utjecaj u modelima LSQ, P50 \% i P90 \%), kao i intenzitet konkurentnosti (pozitivan utjecaj u modelu P25 \%). Kontrolne nezavisne varijable vezane uz karakteristike poduzeća koje imaju statistički značajan utjecaj na zavisnu varijablu (dimenzija reputacije: proizvodi i usluge) su: broj zaposlenih (negativan utjecaj u modelima LSQ, P10 \%, P25 \% i P90 \%), ukupan prihod (negativan utjecaj u modelu P90 \%), djelatnost (pozitivan utjecaj uslužnih djelatnosti u modelu P90 \%) i privatno i javno vlasništvo (pozitivan utjecaj u modelu P10 \% i P90 \%, što ukazuje na višu reputaciju poduzeća u javnom vlasništvu s obzirom na radne odnose), kao i domaće i strano vlasništvo (pozitivan utjecaj u modelu P10 \% i P90 \%, što ukazuje na višu reputaciju poduzeća u stranom vlasništvu s obzirom na radne odnose).

Na temelju prikazanih rezultata može se zaključiti kako se prihvaća treća hipoteza (H3) ovoga rada o utjecaju nezavisnih varijabli kojima se mjeri kvaliteta komunikacije 
DOP-a korištenjem mrežnih stranica, društvenih mreža, karakteristika tržišta i poduzeća na zavisnu varijablu dimenzija reputacije: radni odnosi.

Tablica 23. Statističke značajnosti modela linearne i kvantilne regresije - dimenzija reputacije: radni odnosi

\begin{tabular}{|c|c|c|c|c|c|c|c|}
\hline \multirow{2}{*}{$\begin{array}{c}\text { Grupa nezavisnih } \\
\text { varijabli }\end{array}$} & $\begin{array}{c}\text { Nezavisne } \\
\text { varijable }\end{array}$ & LSQ & $10 \%$ & $25 \%$ & $50 \%$ & $75 \%$ & $90 \%$ \\
\hline & Konstanta & $+1 \%$ & $+1 \%$ & $+1 \%$ & $+1 \%$ & $+1 \%$ & $+1 \%$ \\
\hline \multirow{6}{*}{$\begin{array}{l}\text { Kvaliteta komunikacije } \\
\text { DOP-a korištenjem } \\
\text { mrežnih stranica (H1a) }\end{array}$} & R_avg & $\varnothing$ & $\varnothing$ & $\varnothing$ & $\varnothing$ & $\varnothing$ & $-5 \%$ \\
\hline & U_avg & $\varnothing$ & $-1 \%$ & $\varnothing$ & $\varnothing$ & $\varnothing$ & $+5 \%$ \\
\hline & T_avg & $\varnothing$ & $\varnothing$ & $\varnothing$ & $\varnothing$ & $\varnothing$ & $\varnothing$ \\
\hline & PRAV_avg & $+5 \%$ & $+1 \%$ & $+5 \%$ & $\begin{array}{l}+10 \\
\% *\end{array}$ & $+5 \%$ & $+1 \%$ \\
\hline & J_avg & $\varnothing$ & $-5 \%$ & $\varnothing$ & $\varnothing$ & $\varnothing$ & $-1 \%$ \\
\hline & POU_avg & $\varnothing$ & $+5 \%$ & $\varnothing$ & $\varnothing$ & $\varnothing$ & $-1 \%$ \\
\hline \multirow{2}{*}{$\begin{array}{l}\text { Kvaliteta komunikacije } \\
\text { DOP-a korištenjem } \\
\text { društvenih mreža (H1a) }\end{array}$} & $\begin{array}{l}\text { Facebook_ } \\
\text { da_ne }\end{array}$ & $+5 \%$ & $+1 \%$ & $\varnothing$ & $+1 \%$ & $+1 \%$ & $\varnothing$ \\
\hline & Twitter_da_ne & $\varnothing$ & $\varnothing$ & $\varnothing$ & $\varnothing$ & $\varnothing$ & $\varnothing$ \\
\hline \multicolumn{8}{|c|}{ Kontrolne varijable } \\
\hline $\begin{array}{l}\text { Kategorija kupca (B2B } \\
\text { nasuprot B2C-u) }\end{array}$ & Kat_kupca & $\varnothing$ & $\varnothing$ & $\varnothing$ & $\varnothing$ & $\varnothing$ & $\varnothing$ \\
\hline Rast tržišta & Rast_tržišsta & $+5 \%$ & $\varnothing$ & $\varnothing$ & $+5 \%$ & $\varnothing$ & $+5 \%$ \\
\hline Opseg tržišta & Opseg_tržišta & $\varnothing$ & $\varnothing$ & $\varnothing$ & $\varnothing$ & $\varnothing$ & $\varnothing$ \\
\hline $\begin{array}{l}\text { Intenzitet konkurentnosti } \\
\text { tržišta }\end{array}$ & Intenz_konk & $\varnothing$ & $+5 \%$ & $\varnothing$ & $\varnothing$ & $\varnothing$ & $\varnothing$ \\
\hline \multirow[t]{2}{*}{ Veličina poduzeća } & Br_zap & $-5 \%$ & $-1 \%$ & $-5 \%$ & $\varnothing$ & $\varnothing$ & $-10 \%$ \\
\hline & Uk_prih & $\varnothing$ & $\varnothing$ & $\varnothing$ & $\varnothing$ & $\varnothing$ & $-5 \%$ \\
\hline Djelatnost & $\begin{array}{l}\text { Djelatnost__ } \\
\text { kod }\end{array}$ & $\varnothing$ & $\varnothing$ & $\varnothing$ & $\varnothing$ & $\varnothing$ & $+1 \%$ \\
\hline $\begin{array}{l}\text { Privatno i javno } \\
\text { vlasništvo }\end{array}$ & $\begin{array}{l}\text { Privatno_ } \\
\text { javno }\end{array}$ & $\varnothing$ & $+1 \%$ & $\varnothing$ & $\varnothing$ & $\varnothing$ & $+10 \%$ \\
\hline $\begin{array}{l}\text { Domaće i strano } \\
\text { vlasništvo }\end{array}$ & $\begin{array}{l}\text { Domaće_ } \\
\text { strano }\end{array}$ & $\varnothing$ & $+5 \%$ & $\varnothing$ & $\varnothing$ & $\varnothing$ & $+5 \%$ \\
\hline \multirow[t]{3}{*}{ Regresijska dijagnostika } & $R$ Square & 0,391 & 0,279 & 0,256 & 0,257 & 0,298 & 0,368 \\
\hline & $\begin{array}{l}\text { Adjusted } R \\
\text { Square } \\
\end{array}$ & 0,265 & - & - & - & - & - \\
\hline & $\begin{array}{l}\text { Durbin- } \\
\text { Watson }\end{array}$ & 1,171 & - & - & - & - & - \\
\hline
\end{tabular}

Napomena: $\varnothing$ - parametar nije statistički značajan, $+1 \%$ - pozitivna povezanost uz značajnost od $1 \%,+5 \%$ - pozitivna povezanost uz značajnost od $5 \% ;+10 \%$ - pozitivna povezanost uz značajnost od $10 \%,-1 \%$ - negativna povezanost uz značajnost od $1 \%,-5 \%$ - negativna povezanost uz značajnost od $5 \%$; -10 \% - negativna povezanost uz značajnost od $10 \%$ 


\section{ZAKLJUČAK}

Cilj ovoga rada bio je ispitati povezanost između kvalitete komuniciranja DOP-a putem mrežnih stranica i društvenih mreža i reputacije poduzeća, pri čemu je fokus rada bio na trima dimenzijama: proizvodima i uslugama, vodstvu i radnom okruženju. Prikazano istraživanje prvo je istraživanje o komuniciranju društveno odgovornog poslovanja u Republici Hrvatskoj putem mrežnih stranica i društvenih mreža.

Rezultati istraživanja pokazali su da poduzeća koja imaju veću pravodobnost u objavljivanju sadržaja o DOP-u na mrežnim stranicama i na stranicama Facebooka ujedno imaju veću reputaciju s obzirom na proizvode i usluge. Poduzeća koja posluju na rastućim tržištima imaju veću reputaciju s obzirom na proizvode i usluge, dok poduzeća koja imaju veći broj zaposlenika imaju manju reputaciju s obzirom na proizvode i usluge. Na temelju rezultata testa može se zaključiti kako se prihvaća prva hipoteza ovog rada o utjecaju nezavisnih varijabli kojima se mjeri kvaliteta komunikacije DOP-a korištenjem mrežnih stranica, društvenih mreža, karakteristika tržišta i poduzeća na zavisnu varijablu dimenzija reputacije: proizvodi $i$ usluge. Također, poduzeća koja imaju veću pravodobnost u objavljivanju sadržaja o DOP-u na mrežnim stranicama i koja objavljuju sadržaje vezane uz društvenu odgovornost na stranicama Facebooka imaju veću reputaciju vezanu uz vodstvo. Poduzeća koja posluju na tržištima koja karakterizira rast imaju veću reputaciju s obzirom na vodstvo. Međutim, poduzeća koja imaju veći broj zaposlenika imaju manju reputaciju s obzirom na vodstvo. Na temelju rezultata testa može se zaključiti kako se prihvaća druga hipoteza ovog rada o utjecaju nezavisnih varijabli kojima se mjeri kvaliteta komunikacije DOP-a korištenjem mrežnih stranica, društvenih mreža, karakteristika tržišta i poduzeća na zavisnu varijablu dimenzija reputacije: vodstvo. Isti zaključak slijedi za radno okruženje. Iz rezultata istraživanja može se zaključiti kako poduzeća koja imaju veću pravodobnost u objavljivanju sadržaja o DOP-u na mrežnim stranicama i stranicama Facebooka ujedno imaju i veću reputaciju s obzirom na radno okruženje. Može se zaključiti kako se prihvaća treća hipoteza ovog rada o utjecaju nezavisnih varijabli kojima se mjeri kvaliteta komunikacije DOP-a korištenjem mrežnih stranica, društvenih mreža, karakteristika tržišta i poduzeća na zavisnu varijablu dimenzija reputacije: radni odnosi.

Prilikom analize rezultata istraživanja potrebno je uzeti u obzir ograničenja rada, iz kojih ujedno proizlaze i smjernice za buduća istraživanja. Prvo, istraživanje je provedeno transverzalnim (engl. cross-sectional) pristupom uzevši u obzir komuniciranje poduzeća putem mrežnih stranica i društvenih medija u ograničenom razdoblju, a isti pristup primijenjen je za mjerenje reputacije poduzeća. Drugo, istraživanje je provedeno na ograničenom uzorku poduzeća u Republici Hrvatskoj, čime su rezultati istraživanja ograničeni na nacionalno tržište. Slijedom navedenog proizlazi da bi se buduća istraživanja trebala provesti primjenom longitudinalnog pristupa na većem uzroku poduzeća te usporedbom nekoliko nacionalnih tržišta zemalja sličnih demografskih i gospodarskih karakteristika. 


\section{LITERATURA}

1. Azad, N., \& Hassanabadi, M. (2013). An empirical investigation on factors influencing on brand loyalty. Management Science Letters, 3(7), str. 2113-2118.

2. Barić, A. (2017). Corporate social responsibility and stakeholders: Review of the last decade (2006-2015). Business Systems Research: International journal of the Society for Advancing Innovation and Research in Economy, 8(1), str. 133-146.

3. Barić, A., Omazić, M. A., \& Aleksić, A. (2019, October). Corporate social responsibility and stakeholders' management of export companies in foreign markets. In Proceedings of the ENTRENOVA-ENTerprise REsearch InNOVAtion Conference (Vol. 5, No. 1, pp. 128-135).

4. Bosilj Vukšić, Vesna; Pejić-Bach, Mirjana. (1999). WWW mjesta poduzeća i banaka u Hrvatskoj. Ekonomski pregled. 50(7-8), str. 804-816.

5. Bosilj-Vukšić, V. and Pejić-Bach, M. (1998), „Opening up the company on to the world: WWW sites of the '400 biggest' in Croatia", Proceedings of $9^{\text {th }}$ International Conference on Information and Intelligent Systems, Faculty of Organization and Informatics Varaždin, str. 229-36.

6. Božić, B., Kolić Stanić, M., \& Jurišić, J. (2020, September). Corporate Social Responsibility in the Practice of Public Relations Professionals. In Proceedings of the ENTRENOVA-ENTerprise REsearch InNOVAtion Conference (Online) (Vol. 6, No. 1, pp. 388-397).

7. Butković, L. L., Tomšić, D., \& Kaselj, S. (2021). Collaborative Strategic View in Corporate Social Responsibility-Construction Industry Case. Business Systems Research: International journal of the Society for Advancing Innovation and Research in Economy, 12(1), str. 144-163.

8. Čavić, B. (2010). Elektronska sredstva komunikacije u funkciji unapređenja poslovne komunikacije. Singidunum revija, 7(2), str. 351-361.

9. Fombrun, C. J., Gardberg, N. A. \& Sever, J. M. (2000). The Reputation QuotientSM: a multi-stakeholder measure of corporate reputation. Journal of brand management, 7(4), str. 241-255.

10. Grgić, D. (2008). Instrumenti mjerenja reputacije poduzeća. Tržište, (2), str. 231-249.

11. Grgić, D. (2012). Indeks reputacije poduzeća: empirijsko istraživanje u bankovnom sektoru. Tržište, 24(1), str. 23-45.

12. GRI (2014). Smjernice za izvještavanje o održivosti. Global reporting initiative, 2014.

13. Hartman, L. P., Rubin, R. S., \& Dhanda, K. K. (2007). The communication of corporate social responsibility: United States and European Union multinational corporations. Journal of Business Ethics, 74(4), str. 373-389.

14. Jaković, Božidar; Pejić-Bach, Mirjana; Šimičević, Vanja. (2005). Statistical analysis of the Websites of high category hotels in Croatia. Acta Turistica. 17(2), str. 130-156.

15. Knežević, B., Pejić Bach, M. and Strugar, I. (2007), „Top European retailers and customer centered Web structuring", Zagreb International Review of Economics and Business, 10(1), str. 67-83. 
16. Knežević, B., Renko, S., \& Pejić Bach, M. P. (2011). Web as a customer communication channel in the confectionery industry in South Eastern European countries. British Food Journal, 113(1), str. 17-36.

17. Kolić Stanić, M., \& Barišić, A. F. (2019). Social responsibility and loyalty in public relations codes. Business Systems Research: International journal of the Society for Advancing Innovation and Research in Economy, 10(2), str. 151-162.

18. Kundid, A., \& Rogošić, A. (2012). E-transparency of Croatian Banks: Determinants and Disclosure Contents. Ekonomska istraživanja, (1), str. 86-116.

19. Legendre, S., \& Coderre, F. (2013). Determinants of GRI G3 application levels: the case of the fortune global 500. Corporate Social Responsibility and Environmental Management, 20(3), 182-192.

20. Ozretić Došen, Đ., Previšić, J., i Škare, V. (2003). Komunikacija imagea zemlje putem Web stranica. Zbornik Ekonomskog fakulteta u Zagrebu, 1(1), 149-162.

21. Pejić Bach, Mirjana; Spremić, Mario; Jaković, Božidar. (2007). Cluster Analysis of Croatian Hotel Web Sites Quality Measured with Web Metrics, Proceedings of the $6^{\text {th }}$ WSEAS International Conference on e-Activities / Katehakis, Michael N; Zamora, Antonio; Alvarez, Rafael (ur.). Puerto De La Cruz: WSEAS Press, str. 208-215.

22. Pejić-Bach, Mirjana; Knežević, Blaženka; Pejić-Bach, Miran. (2010). Development of a Web Based Business Oriented Towards a Market Niche in an Emerging Economy: Profightstore.Com., Journal of cases on information technology. 12(2), str. 31-48.

23. Rodolfo, C. H. M. (2012). Examining CSR Reporting and Economic Crisis a Study of GRI Reporting Companies. Asian Economic and Financial Review, 2(1), str. 30-39.

24. Rogošić, A., i Kundid, A. (2012). Izvještavanje o društvenoj odgovornosti banaka u Hrvatskoj. Praktični menadžment, stručni časopis za teoriju i praksu menadžmenta, 3(2), str. 15-20.

25. Samson, R., Mehta, M., \& Chandani, A. (2014). Impact of Online Digital Communication on Customer Buying Decision. Procedia Economics and Finance, 11, str. 872880 .

26. Starešinić, B., Omazić, M. A., \& Aleksić, A. (2019, October). Reputation as a Key Resource for Market Success in the Banking Sector. In Proceedings of the ENTRENOVA-ENTerprise REsearch InNOVAtion Conference (Online) (Vol. 5, No. 1, pp. 264-277). 